\title{
Individual Factorial Structure of Biomechanical and Psychophysiological Indicators as a Basis for Determining the Fighting Style of Qualified Veteran Boxers
}

\author{
Kozin V.Yu. ${ }^{1 \mathrm{ABCD}}$, Boychuk Yu.D. ${ }^{2}{ }^{\mathrm{ABCD}}$, Skaliy A.V. ${ }^{3}$ ABD , Zelenskiy R.M. ${ }^{4 \mathrm{BCD}}$, Honcharenko \\ V.I. ${ }^{5 \mathrm{BCD}}$, Cieślicka M. ${ }^{6 \mathrm{ACD}}$, Bejtka M. ${ }^{6 \mathrm{ACD}}$ \\ ${ }^{1}$ Kinesiology laboratory, H.S. Skovoroda Kharkiv National Pedagogical University, Kharkiv, \\ Ukraine \\ ${ }^{2}$ Rector, H.S. Skovoroda Kharkiv National Pedagogical University, Kharkiv, Ukraine \\ ${ }^{3}$ Institute of Sport and Physical Culture, University of Economy in Bydgoszcz, Poland \\ ${ }^{4}$ Department of Gymnastics, Musical and Rhythmic Education and Fitness, H.S. Skovoroda \\ Kharkiv National Pedagogical University, Kharkiv, Ukraine \\ ${ }^{5}$ Classical professional college of the Sumy State University \\ ${ }^{6}$ Kazimierz Wielki University in Bydgoszcz, Poland
}

Authors' Contribution: A - Study design; B - Data collection; C - Statistical analysis; D Manuscript Preparation; E - Funds Collection

DOI: https://doi.org/10.34142/HSR.2021.07.03.01

Corresponding author: Kozin V.Yu., ORCID: 000-0003-2561-8803, Altshevskih str. 29, Kharkiv, 61002, Ukraine, zhanneta.kozina@ gmail.com

How to Cite

Kozin VYu, Boychuk YuD, Skaliy AV, Zelenskiy RM, Honcharenko VI, Cieślicka M, Bejtka M. Individual factorial structure of biomechanical and psychonhvsiological indicators as a basis for

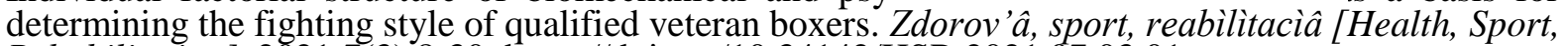
Rehabilitation]. 2021;7(3):8-30. https://doi.org/10.34142/HSR.2021.07.03.01

\begin{abstract}
Purpose: to reveal the fighting style of veteran boxers based on the individual factor structure of psychophysiological and biomechanical indicators.

Material and methods. The study involved 42 qualified veteran boxers (aged 45-50). A biomechanical analysis of the indicators of the movement speed of various points and the values of the joint angles while performing a direct blow by boxers has been used as a research method. The psychophysiological method has been used to determine the time of a simple and complex reaction under standard conditions and in various testing modes. Descriptive Statistics and Factor Analysis have been applied as methods of statistical analysis.

Results. Two main factors have been identified in the structure of the complex performance of qualified veteran boxers,. Factor 1 (55.063\% of the total aggregate variance) is named "Speed". Factor 2 (44.937\% of the total aggregate variance) stands for "Speed Endurance". Individual factor structure, which is characterized by the distinctive factor "Speed and Coordination Endurance" by more than $80 \%$ as well as by the marked factor "Speed" by less than $30 \%$ is considered to be a particularity of the tempo style boxers. Individual factor structure, which is characterized by the intensity of the factor "Speed" by more than $80 \%$, and by the distinctive factor "Speed and Coordination Endurance" by less than $30 \%$ is considered to be typical for the playing style boxers. The individual factor structure, which is characterized by the marked factor "Speed" by more than $50 \%$, and by the intencity of the factor "Speed and Coordination Endurance" by less than $30 \%$ is seen to be peculiar to the strength style boxers.

Conclusions. It is shown that the psychophysiological features of boxers of different fighting styles are reflected in the features of the direct strike technique. The lack of speed at the beginning of the movement in tempo style boxers is supplemented and compensated by the high speed of movement. Playing style boxers are characterized by a high speed of movement at the very beginning of the strike. Strength style boxers are characterized by the gradual development of movement speed.
\end{abstract}

Key words: technique, boxing, neurodynamics, speed, joint angle, physiology, psychology 


\begin{abstract}
Анотація
Козін В.Ю., Бойчук Ю.Д., Скалій О.В., Зеленський Р.М., Гончаренко В.І., Цеслицка М., Бейтка М. Індивідуальна факторна структура біомеханічних і психофізіологічних показників, як основа для визначення стилю ведення бою кваліфікованих боксерів-ветеранів

Мета: виявити стиль ведення поєдинку боксерів-ветеранів на основі індивідуальної факторної структури психофізіологічних і біомеханічних показників.

Матеріал і методи. У дослідженні взяли участь 42 кваліфікованих боксера-ветерана (вік 45-50 років). В якості методів дослідження використовувався біомеханічний аналіз показників швидкості руху різних точок і значення кутів в суглобах при виконанні прямого удару боксерами. Використовувався психофізіологічний метод визначення часу простої і складної реакції в стандартних умовах і в різних режимах тестування. В якості методів статистичного аналізу застосовувався метод описової статистики (Descriptive Statistics) і метод факторного аналізу

Результати. В структурі комплексної підготовленості кваліфікованих боксерів-ветеранів виділено 2 основних фактори. Фактор 1 (55,063 \% від загального сумарної дисперсії) названий «Швидкість». Фактор 2 (44,937\% від загальної сумарної дисперсії) був названий «Швидкісна та координаційна витривалість». Індивідуальна факторна структура, яка характеризується виразністю фактору «Швидкісна та координаційна витривалість» більш, ніж на 80\%, і виразністю фактору «Швидкість» менш, ніж на $30 \%$, характерна для боксерів темпового стилю. Індивідуальна факторна структура, яка характеризується виразністю фактору «Швидкість» більш, ніж на 80\%, і виразністю фактору «Швидкісна та координаційна витривалість» менш, ніж на 30\%, характерна для боксерів ігрового стилю. Індивідуальна факторна структура, яка характеризується виразністю фактору «Швидкість» більш, ніж на 50\%, і виразністю фактору «Швидкісна та координаційна витривалість» менш, ніж на 30\%, характерна для боксерів силового стилю. Висновки. Показано, що психофізіологічні особливості боксерів різних стилів ведення поєдинку відображаються на особливостях техніки прямого удару. Недолік швидкості на початку руху у боксерів темпового стилю доповнюється і компенсується високою швидкістю переміщень. Боксери ігрового стилю відрізняються високою швидкістю рухів на самому початку виконання удару. Боксери силового стилю відрізняються поступовим розвитком швидкості руху.

Ключові слова: техніка, бокс, нейродинамика, швидкість, кут в суглобі, фізіологія, психологія
\end{abstract}

\begin{abstract}
Аннотация
Козин В.Ю., Бойчук Ю.Д., Скалий А.В., Зеленский Р.Н., Гончаренко В.І., Цеслицка М., Бейтка М. Индивидуальная факторная структура биомеханических и психофизиологических показателей, как основа для определения стиля ведения боя квалифицированных боксеров-ветеранов

Цель работы: выявить стиль ведения поединка боксеров-ветеранов на основе индивидуальной факторной структуры психофизиологических и биомеханических показателей.

Материал и методы. В исследовании приняли участие 42 квалифицированных боксера-ветерана (возраст 45-50 лет). В качестве методов исследования испольльзовался биомеханический анализ показателей скорости движения различных точек и значеия углов в суставах при выполении прямого удара боксерами. Использовался психофизиологический метод определения времени простой и сложной реакции в стандартных условиях и в различных режимах тестирования. В качестве методов статистического анализа применялся метод описательной статистики (Descriptive Statistics) и метод факторного анализа

Результаты.В структуре комплексной подготовленности квалифицированных боксеров-ветеранов выделено 2 основных фактора. Фактор 1 (55,063\% от общего суммарной дисперсии) назван «Скорость». Фактор 2 (44,937\% от общего суммарной дисперсии) был назван «Скоростная выносливость». Индивидуальная факторная структура, которая характеризуется выраженностью фактора «Скоростная и координационная выносливость» более чем на 80\%, и выраженностью фактора "Скорость» менее, чем на 30\%, характерная для боксеров темпового стиля. Индивидуальная факторная структура, которая характеризуется выраженностью фактора «Скорость» более чем на 80\%, и выраженностью фактора «Скоростная и координационная выносливость» менее, чем на 30\%, характерная для боксеров игрового стиля. Индивидуальная факторная структура, которая характеризуется выраженностью фактора «Скорость» более чем на 50\%, и выраженностью фактора «Скоростная и координационная выносливость» менее, чем на 30\%, характерная для боксеров силового стиля.
\end{abstract}

Выводы. Показано, что психофизиологические особенности боксеров различных стилей ведения поединка отражаются на особенностях техники прямого удара. Недостаток скорости в начале движения у боксеров-темпового стиля дополняется и компенсируется высокой скоростью перемещений. Боксеры игрового стиля отличаются высокой скоростью движений в самом начале выполнения удара. Боксеры силового стиля отличаются постепенным развитием скорости движения.

Ключевые слова: техника, бокс, нейродинамика, скорость, угол в суставе, физиология, психология 


\section{Introduction}

Currently, the development of veteran sports is being observed. Boxing is no exception $[1,2]$. Boxing for middle-aged and elderly people has different motives: maintaining physical fitness, maintaining and acquiring skills and abilities of selfdefense, relieving psychological stress, and others [2]. Boxing is of particular importance for athletes who have already finished their sports career and who have a certain sports qualification [3-5]. For qualified veteran boxers, in addition to the motives of maintaining their physical shape, maintaining and improving self-defense skills, relieving psychological stress, continuing boxing is important to improve individual skill, sharpening technique, the ability to continue fighting in the ring with equal and superior opponents, the opportunity to feel at the peak struggle and feel like a winner $[2,5]$.

The continuation of sports by qualified athletes has certain specific features. This is due to the fact that with age after 30 years, sarcopenia occurs - a decrease in muscle mass [6]. This is mainly due to the loss of fast muscle fibers, which are responsible for the development of speed and strength. [7, 8] In this case, endurance decreases in a different way than strength and speed, in some cases, up to 35-40 years, endurance even increases [8].

How does the compensation for the loss of strength and speed occur in middle-aged and elderly people who continue boxing? Masters of ancient martial arts continued active classes all their lives, improving their technical skills [1]. This indirectly helps to preserve physical qualities as well [9]. In this regard, the study of the individual technical skill of qualified veteran boxers is important not only for building the training process of middle-aged and elderly boxers, but also from the point of view of a deep understanding of the patterns of individual skill development as sports continue.

The famous martial artist Bruce Lee pointed out that any movement is a manifestation of the human soul [1]. This means that as technical skill improves, there is also an increase in the manifestation of individual psychological and psychophysiological characteristics that characterize the features inherent only in this particular person [3, $10,11]$. Therefore, it is important to study the relationship between the individual characteristics of the technical skill of qualified veteran boxers and their psychophysiological functions. Psychophysiological indicators are a physiological reflection of mental processes, that is, manifestations of the soul, which can be measured instrumentally using objective research methods [12]. A number of studies have shown that psychophysiological indicators are the basis for the style of fighting boxers $[3,12,13]$.

In the modern European tradition, there are several classifications of fighting styles in boxing [3, 14]. For example, the classical international classification of styles in boxing mixes such categories as the distance between opponents and the nature of the blows [15]. This classification distinguishes between outfighters, punchers, swarmers (infighters), sluggers. The outfighter uses fast long strikes. Fighters of this style must have a high impact speed and excellent reaction. The puncher strives to fight at medium range and tries to defeat the opponent with a series of punches. Swarmers or infighters deliver multiple combinations of punches. The most important qualities of a swarmer: Speed and coordination endurance and the ability to maintain good coordination of movements and aggressiveness for a long time to impose a tempo on the opponent. A slugger or brawler often lacks good footwork, which is compensated for by the force of the blow. The most important qualities for a slugger are strength and reaction speed. In the classification adopted in the CIS countries, fighting styles are based on physical qualities [3]. Thus, boxers who win through strong knockout blows are distinguished by high blow power. Power is determined by the product of strength and speed. Therefore, these boxers are characterized by the manifestation of speed-strength abilities, mainly due to strength. This style of fighting is called power. Boxers who win due to their high speed abilities and agility, as well as due to the ability to quickly vary their actions, belong to the playing style of the fight. Boxers who impose a tempo on the opponent and are able to maintain this tempo for a long time to wear down their opponents belong to the tempo style of fighting [16].

Currently, no studies have been carried out to identify analogies between the European classification and the classification adopted in the CIS countries. However, both the European classification and the classification adopted in the CIS countries have some common features. So, the reaction speed is one of the defining qualities for the formation of the style of the duel [17-20]. The reaction speed is one of the manifestations of psychophysiological functions that determine the style of fighting $[3,12,19]$.

There are many different methods for measuring psychophysiological functions: direct methods that are directly related to surgical intervention in the brain and indirect, but no less objective [21-24]. For example, indirect methods for studying the psychophysiological characteristics of a 
person include measuring the speed of reaction to a viewed object, to sound, to an object that changes its position in space, the ability to accurately reproduce certain intervals of time, and others [21, 23]. At present, methods of studying psychophysiological functions are becoming more widespread, which make it possible to determine not only the reaction rate, the sense of time, but also the typological properties of the nervous system: strength, mobility, resistance to stimuli in time. It can be noted that at present psychophysiological methods of research make it possible to instrumentally objectively record the manifestations of the "soul" $[12,13]$.

The features of a technical master, which are the basis for the style of activity, are determined using biomechanical research methods, which involve video analysis of the trajectory, speed, time of movement of various points of the body in space, as well as analysis of criminality in the joints in the dynamics of movements [15, 25-27].

Currently, the study of psychophysiological functions in connection with the individual characteristics of the technique of movements according to biomechanical indicators is of great importance. This makes it possible to quantitatively determine how and how the peculiarities of brain activity affect the formation of an individual style of human activity $[3,12,13]$. For this purpose, qualified veteran boxers are one of the most suitable contingents for such studies for several reasons: 1 as a person's age increases, there is an improvement in technical skill while continuing to engage in a certain type of activity, including sports; 2 - as the age increases, the manifestation of individual psychological and psychophysiological traits occurs; 3 - the study of the peculiarities of technical mastery of qualified athletes of middle and elderly age in conjunction with the individual characteristics of psychophysiological functions is important as a tool for cognition of motor and psychophysiological manifestations of various styles of activity [2].

However, there is much less scientific research on veteran athletes today than on younger active athletes. This provision concerns all aspects of studying the characteristics of the training process of qualified athletes: the development of physical qualities (strength, speed, endurance, flexibility, dexterity), psychological preparation, improvement of technical skill, alternation of load and rest, the use of various methods of restoration of working capacity and other aspects [28] ... Despite the high relevance, the least studied issue is the relationship between the characteristics of technical skill and psychological (psychophysiological) functions. Therefore, the determination of the relationship between psychophysiological and biomechanical indicators at the present stage is a relatively new, previously not studied, task.

The study of relationships is traditionally carried out using correlation analysis [29]. At the present stage, the use of factor analysis is also very widespread [30]. Factor analysis is used when it is necessary to identify the relationship between a large number of indicators and reduce these indicators to a smaller number of factors. Each factor brings together a group of the most interrelated indicators. Indicators included in different groups, while little related to each other. Thus, the determination of the factor structure of various aspects of any state (including the fitness of athletes) allows us to reveal the hidden relationships between different indicators reflecting different aspects of this state, in our case, the fitness of athletes [31].

In sports, it is also relevant to identify the individual severity of each factor for each case (athlete). This makes it possible to analyze the characteristics of the readiness of each athlete not only by individual indicators, but in a complex way, by groups of interrelated indicators. Thus, an individual factorial structure of athletes' fitness is obtained [31, 32].

In this regard, in order to identify the relationship between the peculiarities of the nervous system and the technical skill of athletes, it is most expedient at present to determine the general and individual factor structure of readiness based on the analysis of biomechanical and psychophysiological indicators.

Purpose: to reveal the fighting style of veteran boxers based on the individual factor structure of psychophysiological and biomechanical indicators.

\section{Material and methods}

\section{Participants}

The study involved 42 qualified veteran boxers (age 45-50 years, body length - 178.67 \pm 8.26 $\mathrm{cm}$, body weight $-70.96 \pm 9.38 \mathrm{~kg}$ ). The total experience of boxing for the participants was 20-25 years. Athletes differed in the following way: a prerequisite for participation in the study was the presence of a sports qualification in the past not lower than a candidate for master of sports (winners of competitions not lower than the city and regional level) and the regularity of training for the last 10 years 3-4 times a week. The study was carried out on the basis of sports clubs "KhTZ", "Vostok", "Metalist" in Kharkov, Ukraine. 
All participants were aware of the objectives of the study and agreed to participate.

\section{Procedure}

The study was conducted from April 18 to May 25, 2021. At first, video filming of athletes was carried out when performing a direct blow in boxing. Each athlete performed a series of strikes alternately with the right and left hands in the training session against the background of a visible object for subsequent calibration with known dimensions. Video filming was carried out at training sessions from 18-00 after a short warm-up in the boxing gym of the KhTZ sports club. During one training session, 10-12 people were filmed. The next day after the video filming, the athletes underwent psychophysiological testing also from 18-00. When conducting psychophysiological testing, athletes were initially asked to pass the proposed tests in a training mode. Psychophysiological testing was carried out in the classroom for theoretical studies of the sports club "KhTZ".

\section{Biomechanical Analysis of Direct Punch Technique in Boxing}

We have chosen the direct punch as the main element for the analysis of the athletic technique of qualified veteran boxers. The choice of direct hit was due to the fact that it is the main technical element in boxing. This stroke is the most standardized of all boxing elements and provides the least variability in execution. This element is perfectly mastered by all qualified boxers, in particular - veteran boxers. Also, the individual style of movements is most traced precisely in those movements that are performed most automatically, that is, with minimal control from the side of consciousness. This blow is the most convenient for biomechanical analysis using video filming, since it is performed practically in the same plane.

Biomechanical analysis of the direct kick technique in qualified veteran boxers was carried out using the Kinovea software, version 0.8.15. (Fig. 1). Kinovea software allows you to perform video motion analysis. It is intended for athletes, coaches, health professionals, and sports research. Also, the software can be useful for specialists in the field of ergonomics or animation. The main function of Kinovea is to view and analyze sports videos. The main tools used by users are "Line", "Chronometer", "Tracking", "Angles". The Line and Chronometer functions allow you to measure distance and time, while the Semi-automatic tracking tool can track both path and time. When working with Kinovea, you can use video from external sources: video cameras, smartphones, and so on [33, 34].

To analyze the biomechanical parameters of the direct strike technique of qualified veteran boxers, 6 frames were selected at a speed of 26 frames per second. Thus, the time of one frame was 0.03-0.04 s (Fig. 1-3). The duration of the direct impact was $0.13-0.16 \mathrm{~s}$, depending on how many frames were analyzed (5 or 6 , respectively). The distance was calibrated along the length of a special device, against the background of which video filming was carried out $(138 \mathrm{~cm})$. The movement time was determined by the stopwatch indicators in the program. The speed of movement of the fist, shoulder joint, elbow joint, knee joint was determined (V, ms-1) (Fig. 1). We also determined the angles between the shoulder and the torso (angle at the shoulder joint), between the shoulder and forearm (angle at the elbow joint), between the thigh and lower leg (angle at the knee joint) (degrees) (Fig. $1)$.

A total of 10 videos of a direct hit were analyzed for each athlete. Of the 10 videos, the best movement speed metrics were analyzed for each athlete. The total number of video recordings was 420. The point of greatest extension of the striking arm in the elbow and shoulder joints was chosen as the end of the impact. In each video, 6 frames were selected for analysis (duration of a direct impact). If the impact ended on the fifth frame, then the sixth frame was excluded from the analysis. Earlier in the fifth frame, more than one athlete did not end up with a direct hit. Thus, the total duration of a direct blow in boxing among qualified veteran boxers was 0.13$0.16 \mathrm{~s}$ : the first frame $-0 \mathrm{~s}$ (start of movement), the second frame $-0.03 \mathrm{~s}$, the third frame $-0.06 \mathrm{~s}$, the fourth frame is $0.10 \mathrm{~s}$, the fifth frame is $0.13 \mathrm{~s}$, and the sixth frame is $0.16 \mathrm{~s}$. The point of the minimum angle between the shoulder and the torso (shoulder joint), from which the movement of the striking arm begins, was chosen as the start of the strike. Some athletes performed a swing first and pulled their arm back before starting the strike. For these athletes, the point was taken as the beginning of the strike, from which the forward movement of the striking arm began. The angle at the shoulder joint in this case had a negative value.

To analyze the angles in the joints, the "Angles" tool was selected on the toolbar of the Kinovea 0.8 .15 program. The point of the apex of the angle was selected, then the angle for analysis was determined. The angle chosen for analysis was determined in each frame (Fig. 1). 


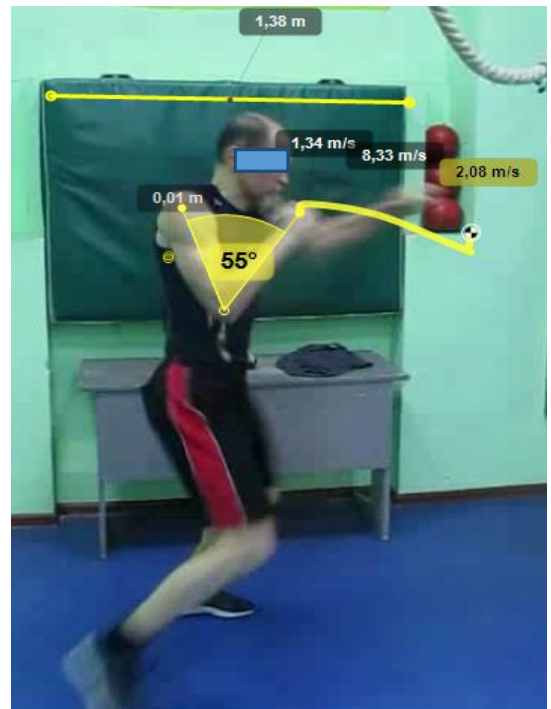

Fig. 1. Determination of the speed of movement of various points of the body and angles in the joints when performing a direct blow in boxing using the program Kinovea 08.15

Tracking the trajectory for the subsequent analysis of the distance and speed of movement of each point, we carried out as follows (Fig. 1): 1 select a point for analysis; 2 - select the "Track Path" option; choose the "End Path Edition" function; 3 the analyzed point was corrected for each frame; 4 Select the "Configuration" function and set the "Distance" function. The display showed the distance from the beginning of the movement to the selected segment of the path. To measure the speed of a point, we selected the "Configuration" function, and then we selected the "Speed" function. We chose meters per second as the unit of measurement. The measurement results were exported to the EXCEL program.

\section{Psychophysiological methods}

With the help of the computer program "Psychodiagnostics" (Kharkiv, Ukraine, KhNPU), the following parameters were established that characterize the psychophysiological state, typological features of the nervous system, indicators of the performance of the nervous system and indicators of attention [35]:

- a set of indicators of the time of a simple visual-motor reaction (average value of 30 attempts (ms), standard deviation (ms), number of errors; duration of exposure (signal) - $900 \mathrm{~ms}$.

- a set of indicators of a complex visualmotor reaction of choosing 2 elements out of 3 (average value of 30 attempts (ms), standard deviation (ms), number of errors; duration of exposure (signal) - $900 \mathrm{~ms}$.
- a set of indicators of a complex visualmotor reaction of the choice of 2 elements out of 3 in the feedback mode, i.e. when the response time changes, the signaling time changes.

The "short version" is carried out in the feedback mode, when the duration of exposure changes automatically depending on the response of the subject: after the correct answer, the duration of the next signal is reduced by $20 \mathrm{~ms}$, and after the wrong one, it increases by the same amount. The range of variation of the signal exposure during the work of the subject is $20-900 \mathrm{~ms}$, with a pause between exposures of $200 \mathrm{~ms}$. The correct answer is to press the left (right) mouse button when displaying a certain exposure (image) or during a pause after the current exposure. In this test, the time to reach the minimum signal exposure and the time to the minimum signal exposure reflect the functional mobility (speed) of nervous processes; the number of errors reflects the strength of nervous processes (the lower these parameters, the higher the speed endurance of the nervous system) $[12,13,36]$. The duration of the initial exposure is $900 \mathrm{~ms}$; the value of the change in the duration of signals with correct or erroneous answers is $20 \mathrm{~ms}$; pause between signal presentation - $200 \mathrm{~ms}$; number of signals - 50 . Indicators. which were recorded: the average value of the latency period (ms); standard deviation (ms); number of mistakes; test execution time (s); minimum holding time (ms); time to reach minimum signal exposure (s).

\section{Statistical analysis}

We used the following statistical analysis methods using the SPSS - 17.0 program.

1. Descriptive statistics (Analyze Descriptive Statistics). We used this method to get an overview of the analyzed sample of qualified veteran boxers. We calculated the following indicators: Minimum, Maximum, Mean value $(\bar{x})$, standard deviation (S). In total, 52 indicators were analyzed, of which - 42 indicators of the biomechanics of the direct hitting technique in boxing and 10 indicators of the psychophysiological capabilities of athletes.

2 . Factor analysis by the method of principal components. We used factor analysis to identify hidden relationships between variables and to reduce 52 analyzed indicators to fewer factors. We also used factor analysis to determine the individual severity of each factor for each athlete. For each athlete, the values of a large number of variables were translated into values of a small number of factors.

Before carrying out the factor analysis, all indicators of the examined athletes were checked using the Chi-square test for compliance with the 
normal distribution. After obtaining the results confirming the compliance with the normal distribution of all indicators used in factor analysis, further calculations were carried out, requiring compliance with the normal distribution of the analyzed indicators. At the beginning of the factor analysis procedure, we analyzed the correlation matrix. Correlation analysis showed that most indicators are closely correlated with each other $(\mathrm{r}=$ 0.7-0.9; $<<0.05 ; \mathrm{p}<0.01 \mathrm{p}<0.001$ ) (Appendix 1).

Factor analysis was performed using the following SPSS 17.0 software options: Analyze Dimension Reduction - Factor. We have chosen to infer the following data: Initial solution, Correlation matrix, eigenvalues of factors. When generating the factors, the default option was left: the eigenvalues of the factors are greater than 1. Thus, in the explained Total Variance Explained, the factors were formed only by those components whose eigenvalues are greater than 1. The maximum number of iterations for convergence was also left the default is 25 . The rotation method was chosen Varimax with Kaiser normalization. The option was used to derive factor loadings (correlation coefficients between individual variables and factors) after rotation. Factor loads were sorted in descending order. The derivation of factor loadings (correlation coefficients of indicators with factors) less than 0.7 was excluded. The derivation of indicators with unreliable factor loadings was also excluded. Based on the analysis of the indicators that were included in each factor, we gave names to the factors.

We used the values of the factors for each case (for each athlete) in absolute values and in values expressed as a percentage of the maximum value for a given sample. Thus, we have obtained a general and individual factor structure of the complex readiness of qualified veteran boxers based on the analysis of biomechanical and psychophysiological indicators.

\section{Results}

The analysis of biomechanical and psychophysiological indicators of qualified veteran boxers showed the following (Table 1). The average values of the speed of a simple visual-motor reaction, a choice reaction, a choice reaction in the feedback mode, the time to reach the minimum signal exposure, the time of the minimum signal exposure, the total test execution time among qualified veteran boxers does not differ from the values of qualified boxers and representatives of other martial arts aged 18-25 years [3, 11]. However, the number of errors in the selection reaction test in the feedback mode in our sample was less than in younger athletes. For young qualified boxers this value was 22-23 errors, for veteran boxers this value was $18.67 \pm 1.26$, Minimum $=17$, Maximum $=20$. The data obtained indicate that qualified veteran boxers have a higher ability to maintain high efficiency of the nervous system when performing tasks that require high speed and accuracy within a certain period of time (90-120 s). This also indicates that qualified veteran boxers have higher speed and coordination endurance of the nervous system.

The greatest scatter in the values of the angles in the joints was detected at 1-2 frames (0-0.03 $\mathrm{s}$ from the beginning of the movement) (Table 1). This is due to the fact that some boxers, at the beginning of a direct blow, perform a backward movement with their hand for a swing. As a result, the maximum angle at the shoulder joint at the beginning of the movement is (-7.00) degrees. However, most athletes perform this movement from a positive shoulder position. At the end of the movement (4-6 frames, 0.10-0.16 $\mathrm{s}$ from the beginning of the movement) the value of the angle in the shoulder joint is $65.33 \pm 0.95$ degrees (Table 1). The angles in the elbow joint range from $65.33 \pm 0.95$ to $158.33 \pm 10.66$ degrees. The angles in the knee joint are $135.00 \pm 7.16$ degrees to $154.67 \pm 12.04$ degrees (Table 1).

Thefist movement speed ranges from $2.28 \pm$ $0.83 \mathrm{~m} \cdot \mathrm{s}-1$ to $9.78 \pm 1.64 \mathrm{~m} \cdot \mathrm{s}-1$. The shoulder movement speed ranges from $1.60 \pm 0.66 \mathrm{~m} \cdot \mathrm{s}^{-1}$ to $3.34 \pm 1.73 \mathrm{~m} \cdot \mathrm{s}^{-1}$. The elbow movement speed ranges from $1.68 \pm 0.20 \mathrm{~m} \cdot \mathrm{s}^{-1}$ to $5.75 \pm 1.84 \mathrm{~m} \cdot \mathrm{s}^{-1}$. The knee movement speed ranges from $0.55 \pm 0.16 \mathrm{~m} \cdot \mathrm{s}^{-1}$ to $2.31 \pm 0.18 \mathrm{~m} \cdot \mathrm{s}^{-1}$ (Table 1$)$.

Table 1

Values of biomechanical and psychophysiological indicators of qualified veteran boxers

\begin{tabular}{|l|c|c|c|c|}
\hline \multicolumn{1}{|c|}{ Indicators } & Minimum & Maximum & $\bar{x}$ & S \\
\hline Simple visual-motor reaction time (ms) & 292.00 & 314.00 & 302.00 & 9.20 \\
\hline Selection response time (ms) & 525.00 & 590.00 & 561.00 & 27.32 \\
\hline Errors in the test for reaction of choice (number) & 1.00 & 13.00 & 8.67 & 5.50 \\
\hline Standard deviation of selection response time (ms) & 3.61 & 3.72 & 3.65 & 0.05 \\
\hline Selection response time in feedback mode (ms) & 449.00 & 513.00 & 471.67 & 29.63 \\
\hline
\end{tabular}




\begin{tabular}{|c|c|c|c|c|}
\hline $\begin{array}{l}\text { Errors in the selection reaction test in the feedback } \\
\text { mode (number) }\end{array}$ & 17.00 & 20.00 & 18.67 & 1.26 \\
\hline $\begin{array}{l}\text { Standard deviation of response time of selection in } \\
\text { feedback mode (ms) }\end{array}$ & 3.84 & 4.05 & 3.98 & 0.10 \\
\hline $\begin{array}{l}\text { The minimum signal exposure time in the test for the } \\
\text { selection reaction in the feedback mode (ms) }\end{array}$ & 400.00 & 540.00 & 460.00 & 59.59 \\
\hline $\begin{array}{l}\text { Total time to complete the test for the selection } \\
\text { reaction in the feedback mode (s) }\end{array}$ & 94.00 & 107.00 & 99.33 & 5.63 \\
\hline $\begin{array}{l}\text { Time to reach the minimum exposure of the signal in } \\
\text { the test for the selection reaction in the feedback mode } \\
\text { (s) }\end{array}$ & 43.00 & 73.00 & 55.33 & 12.97 \\
\hline Shoulder angle at position $* 1$ (degrees) & -12.00 & 37.00 & 12.25 & 16.45 \\
\hline Shoulder angle at position 2 (degrees) & -7.00 & 38.00 & 15.50 & 17.63 \\
\hline Shoulder angle at position 3 (degrees) & 55.00 & 77.00 & 67.00 & 9.20 \\
\hline Shoulder angle at position 4 (degrees) & 78.00 & 86.00 & 82.33 & 3.34 \\
\hline Shoulder angle at position 5 (degrees) & 75.00 & 96.00 & 86.33 & 8.76 \\
\hline Shoulder angle at position 6 (degrees) & 75.00 & 96.00 & 86.33 & 8.76 \\
\hline Elbow angle at position 1 (degrees) & 58.00 & 91.00 & 70.67 & 14.70 \\
\hline Elbow angle in position 2 (degrees) & 64.00 & 66.00 & 65.33 & 0.95 \\
\hline Elbow angle at position 3 (degrees) & 49.00 & 82.00 & 69.33 & 14.70 \\
\hline Elbow angle at position 4 (degrees) & 107.00 & 160.00 & 130.67 & 22.27 \\
\hline Elbow angle at position 5 (degrees) & 144.00 & 169.00 & 158.33 & 10.66 \\
\hline Elbow angle at position 6 (degrees) & 122.00 & 177.00 & 150.00 & 22.74 \\
\hline Knee angle in position 1 (degrees) & 119,00 & 147,00 & 137,00 & 12,91 \\
\hline Knee angle in position 2 (degrees) & 125.00 & 140.00 & 135.00 & 7.16 \\
\hline Knee angle in position 3 (degrees) & 128.00 & 148.00 & 137.67 & 8.28 \\
\hline Knee angle in position 4 (degrees) & 142.00 & 157.00 & 147.33 & 6.93 \\
\hline Knee angle in position 5 (degrees) & 143.00 & 163.00 & 151.67 & 8.48 \\
\hline Knee angle in position 6 (degrees) & 143.00 & 171.00 & 154.67 & 12.04 \\
\hline Fist movement speed in position $1\left(\mathrm{~m} \cdot \mathrm{s}^{-1}\right)$ & 0.00 & 0.00 & 0.00 & 0.00 \\
\hline Fist movement speed in position $2\left(\mathrm{~m} \cdot \mathrm{s}^{-1}\right)$ & 1.15 & 3.09 & 2.28 & 0.83 \\
\hline Fist movement speed in position $3\left(\mathrm{~m} \cdot \mathrm{s}^{-1}\right)$ & 4.63 & 17.52 & 9.78 & 1.64 \\
\hline Fist movement speed in position $4\left(\mathrm{~m} \cdot \mathrm{s}^{-1}\right)$ & 6.47 & 11.50 & 8.37 & 1.26 \\
\hline Fist movement speed in position $5\left(\mathrm{~m} \cdot \mathrm{s}^{-1}\right)$ & 2.07 & 8.74 & 5.56 & 1.76 \\
\hline Fist movement speed in position $6\left(\mathrm{~m} \cdot \mathrm{s}^{-1}\right)$ & 0.86 & 3.31 & 2.47 & 0.15 \\
\hline Shoulder speed in position $1\left(\mathrm{~m} \cdot \mathrm{s}^{-1}\right)$ & 0.00 & 0.00 & 0.00 & 0.00 \\
\hline Shoulder speed in position $2\left(\mathrm{~m} \cdot \mathrm{s}^{-1}\right)$ & 1.29 & 2.37 & 1.88 & 0.45 \\
\hline Shoulder speed in position $3\left(\mathrm{~m} \cdot \mathrm{s}^{-1}\right)$ & 1.74 & 5.71 & 3.34 & 1.73 \\
\hline Shoulder speed in position $4\left(\mathrm{~m} \cdot \mathrm{s}^{-1}\right)$ & 1.06 & 2.52 & 1.60 & 0.66 \\
\hline Shoulder speed in position $5\left(\mathrm{~m} \cdot \mathrm{s}^{-1}\right)$ & 1.06 & 2.41 & 1.79 & 0.56 \\
\hline Shoulder speed in position $6\left(\mathrm{~m} \cdot \mathrm{s}^{-1}\right)$ & 0.66 & 0.91 & 0.80 & 0.11 \\
\hline Elbow speed in position $1\left(\mathrm{~m} \cdot \mathrm{s}^{-1}\right)$ & 0.00 & 0.00 & 0.00 & 0.00 \\
\hline Elbow speed in position $2\left(\mathrm{~m} \cdot \mathrm{s}^{-1}\right)$ & 1.65 & 2.89 & 2.45 & 0.57 \\
\hline Elbow speed in position $3\left(\mathrm{~m} \cdot \mathrm{s}^{-1}\right)$ & 3.17 & 7.04 & 5.75 & 1.84 \\
\hline Elbow speed in position $4\left(\mathrm{~m} \cdot \mathrm{s}^{-1}\right)$ & 4.32 & 5.94 & 5.36 & 0.75 \\
\hline Elbow speed in position $5\left(\mathrm{~m} \cdot \mathrm{s}^{-1}\right)$ & 1.51 & 4.74 & 3.27 & 1.35 \\
\hline Elbow speed in position $6\left(\mathrm{~m} \cdot \mathrm{s}^{-1}\right)$ & 1.50 & 1.96 & 1.68 & 0.20 \\
\hline Knee speed in position $1\left(\mathrm{~m} \cdot \mathrm{s}^{-1}\right)$ & 0.00 & 0.00 & 0.00 & 0.00 \\
\hline Knee speed in position $2\left(\mathrm{~m} \cdot \mathrm{s}^{-1}\right)$ & 1.39 & 3.81 & 2.31 & 0.18 \\
\hline Knee speed in position $3\left(\mathrm{~m} \cdot \mathrm{s}^{-1}\right)$ & 0.83 & 5.10 & 2.29 & 2.01 \\
\hline Knee speed in position $4\left(\mathrm{~m} \cdot \mathrm{s}^{-1}\right)$ & 0.36 & 3.81 & 1.70 & 1.53 \\
\hline Knee speed in position $5\left(\mathrm{~m} \cdot \mathrm{s}^{-1}\right)$ & 0.29 & 0.91 & 0.55 & 0.16 \\
\hline Knee speed in position $6\left(\mathrm{~m} \cdot \mathrm{s}^{-1}\right)$ & 0.23 & 1.69 & 1.11 & 0.64 \\
\hline
\end{tabular}

Notes: ${ }^{*}$ position 1 - frame $1,0 \mathrm{~s}$ from the beginning of the movement (the beginning of the movement); position 2 frame 2, 0.03 s from the beginning of the movement; position 3 - frame $3,0.06 \mathrm{~s}$ from the beginning of the movement; position 4 - frame 4, $0.10 \mathrm{~s}$ from the beginning of the movement; position 5 - frame 5, $0.13 \mathrm{~s}$ from the beginning of the movement; position 5 - frame $6,0.16$ s from the beginning of the movement

The test for normality of distribution of test indicators showed that all test indicators correspond to the normal distribution (Asymptomatic significance according to the $\chi^{2}$ test $>0.05$; significance according to the Monte Carlo test> 0.05). The distribution of indicators of the analyzed sample does not significantly differ from the Gaus normal distribution (Table 2). 
Table 2

$\chi^{2}$ testtest results of biomechanical and psychophysiological indicators of qualified veteran boxers $(\mathrm{n}=42)$

\begin{tabular}{|c|c|c|c|c|c|c|c|c|}
\hline \multicolumn{2}{|c|}{ 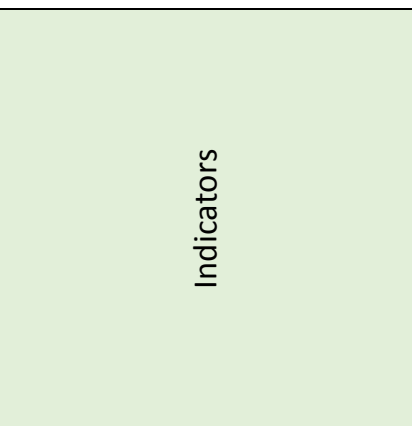 } & 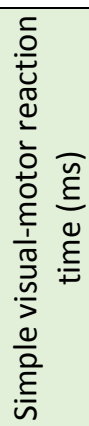 & 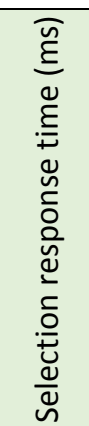 & 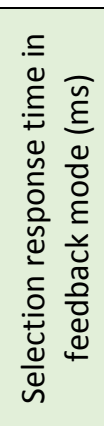 & 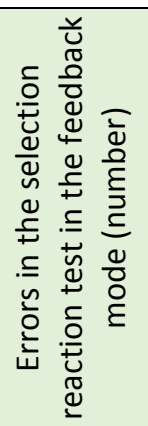 & 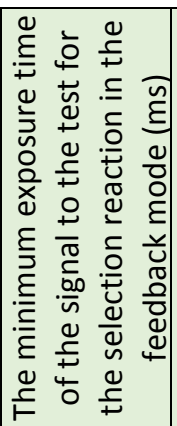 & 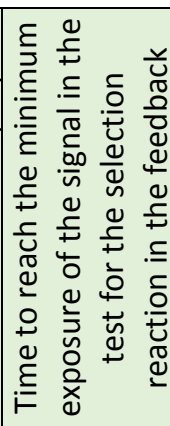 & 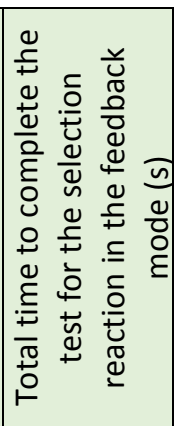 \\
\hline \multicolumn{2}{|c|}{$\chi^{2}$} & 1.71 & 3.71 & 0.00 & 4.286 & 0.00 & 0.00 & 0.00 \\
\hline \multicolumn{2}{|c|}{ df } & 41 & 41 & 41 & 41 & 41 & 41 & 41 \\
\hline \multicolumn{2}{|c|}{ Asymp. Sig. } & 0.2 & 0.90 & 0.009 & 0.09 & 0.99 & 0.99 & 0.99 \\
\hline $\begin{array}{l}\text { Monte Carlo } \\
\text { Sig. }\end{array}$ & Sig. & 0.48 & 0.90 & 0.999 & 0.525 & 0.99 & 0.99 & 0.99 \\
\hline \multirow{2}{*}{$\begin{array}{c}95 \% \\
\text { Confidence } \\
\text { Interval }\end{array}$} & Lower Bound & 0.47 & 0.00 & 0.976 & 0.515 & 0.97 & 0.97 & 0.97 \\
\hline & Upper Bound & 0.49 & 0.01 & 0.999 & 0.534 & 0.99 & 0.99 & 0.99 \\
\hline
\end{tabular}

Table 2

Continuation

\begin{tabular}{|c|c|c|c|c|c|c|c|c|c|c|c|c|c|c|c|}
\hline \multicolumn{2}{|c|}{$\begin{array}{l}\frac{n}{0} \\
\stackrel{0}{0} \\
\frac{0}{0} \\
\underline{\underline{0}}\end{array}$} & 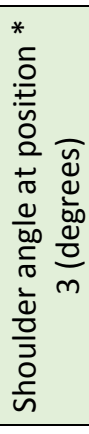 & 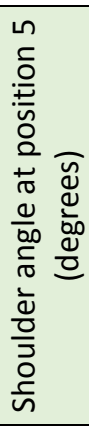 & 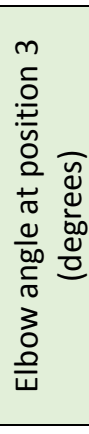 & 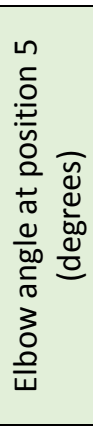 & 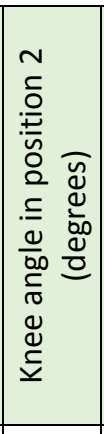 & 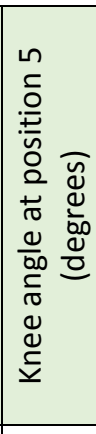 & 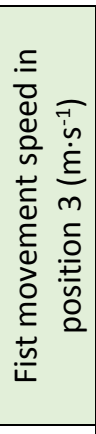 & 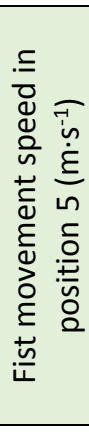 & 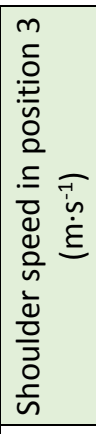 & 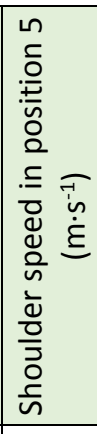 & 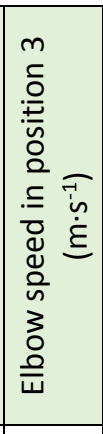 & 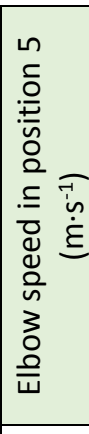 & 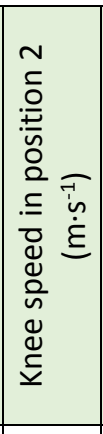 & 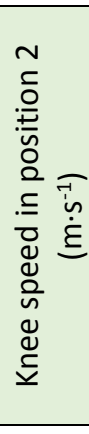 \\
\hline \multicolumn{2}{|c|}{ Chi-Square } & 0.00 & 1.71 & 7.71 & 0.00 & 4.286 & 4.286 & 0.00 & 0.00 & 4.286 & 2.571 & 5.143 & 0.00 & 5.143 & 0.00 \\
\hline \multicolumn{2}{|c|}{$\mathrm{df}$} & 41 & 41 & 41 & 41 & 41 & 41 & 41 & 41 & 41 & 41 & 41 & 41 & 41 & 41 \\
\hline \multicolumn{2}{|c|}{ Asymp. Sig. } & 0.99 & 0.42 & 0.90 & 0.99 & 0.509 & 0.50 & 0.99 & 0.99 & 0.50 & 0.46 & 0.27 & 0.99 & 0.273 & 0.99 \\
\hline $\begin{array}{c}\text { Monte } \\
\text { Carlo } \\
\text { Sig. }\end{array}$ & Sig. & 0.99 & 0.48 & 0.00 & 0.99 & 0.525 & 0.52 & 0.99 & 0.99 & 0.52 & 0.49 & 0.27 & 0.99 & 0.279 & 0.9 \\
\hline \multirow{2}{*}{$\begin{array}{c}95 \% \\
\text { Confide } \\
\text { nce } \\
\text { Interval }\end{array}$} & $\begin{array}{l}\text { Lower } \\
\text { Bound }\end{array}$ & 0.97 & 0.47 & 0.00 & 0.97 & 0.515 & 0.51 & 0.97 & 0.97 & 0.51 & 0.48 & 0.27 & 0.99 & 0.27 & 0.97 \\
\hline & $\begin{array}{l}\text { Upper } \\
\text { Bound }\end{array}$ & 0.99 & 0.49 & 0.01 & 0.99 & 0.534 & 0.53 & 0.99 & 0.99 & 0.53 & 0.50 & 0.28 & 0.99 & 0.288 & 0.99 \\
\hline
\end{tabular}

Notes: * position 1 - frame 1, $0 \mathrm{~s}$ from the beginning of the movement (the beginning of the movement); position 2 frame 2, $0.03 \mathrm{~s}$ from the beginning of the movement; position 3 - frame $3,0.06 \mathrm{~s}$ from the beginning of the movement; position 4 - frame $4,0.10 \mathrm{~s}$ from the beginning of the movement; position 5 - frame $5,0.13 \mathrm{~s}$ from the beginning of the movement; position 5 - frame $6,0.16 \mathrm{~s}$ from the beginning of the movement

At the beginning of the factor analysis procedure, we analyzed the correlation matrix. Correlation analysis showed that most indicators are closely correlated with each other $(r=0.7-0.9 ; \mathrm{p}$ $<0.05 ; \mathrm{p}<0.01 \mathrm{p}<0.001)$.
With the help of factor analysis, carried out by the method of principal components, in the structure of the complex readiness of qualified veteran boxers, 2 main factors were identified by the methods of Total Variance Explained and Kettel's 
"scree" (Table 3, Fig. 2). It should be noted that the total variance explains almost $100 \%$ of the squares of factor loadings (Table 3). This testifies to the large number and high reliability of the relationships between the indicators selected for factor analysis. To characterize each factor, the indicators included in it were analyzed.

The first factor $(55.063 \%$ of the total total variance) (Table 3 ) included the following indicators: the angle at the shoulder joint at the beginning of movement $(r=0.999)$, the speed of the fist at the beginning of the movement $(r=0.974)$, the speed of the shoulder at the beginning movement $(r=0.972)$, angle at the knee joint at the end of the movement ( $\mathrm{r}$ $=0.67)$, choice reaction time $(r=-0.956)$, time of simple visual-motor reaction $(r=-0.802)$, shoulder movement speed at the end movements $(r=-0.789)$, errors in the selection reaction in the feedback mode $(r=0.782)$, the total time of the test for the selection reaction in the feedback mode $(r=-0.707)$ (Table 4).

It should be noted that the first factor included indicators reflecting the level of speed of the nervous system (the time of a simple visual-motor reaction, the reaction time of choice, the total time of the test in the feedback mode) with a negative correlation coefficient. The shorter the reaction time, the higher the speed of the nervous system. For this, it can be noted that the first factor includes indicators reflecting the speed of the nervous system. In addition, the first factor included indicators reflecting the speed of movements at the beginning of a direct blow in boxing (shoulder speed and speed of fist movement) with a positive correlation coefficient and the speed of shoulder movement at the end of a direct blow in boxing with a negative correlation coefficient.

That is, the speed of the nervous system is positively related to the speed of movements at the beginning of a direct strike and is negatively related to the speed of shoulder movement at the end of a direct strike. It is no coincidence that the first factor included the indicator of the angle in the shoulder joint at the beginning of the strike with a positive relationship. The greater the speed of movement of the shoulder, the greater the value and angle in the shoulder joint. But the first factor also included the indicator of the number of errors in the test for the response of choice in the feedback mode. This indicates that with an increase in the speed of movements and the speed of the nervous system, the speed endurance of the nervous system decreases, that is, the ability to maintain high accuracy with increasing speed over time. As for motor abilities, this fact has an explanation, since endurance and speed are antagonists $[31,32]$.
From the data obtained, it follows that the work of the nervous system has the same regularities as the work of the muscular apparatus. This is not accidental, since the muscular work characteristic of any movement is guided by the nervous system [3739]. And therefore, the properties of the nervous system also affect the speed and accuracy of movements over time. Thus, the first factor included indicators that reflect the speed of movements at the beginning of a direct blow in boxing, the speed of the nervous system and are negatively associated with the speed endurance of the nervous system. Based on the analysis of the indicators included in the first factor, this factor was named "Speed".

The second factor $(44.937 \%$ of the total total variance) (Table 3) included the following indicators: the speed of the shoulder movement at the end of the movement $(r=0.892)$, the number of errors in the selection reaction test in the feedback mode $(r=-0.985)$, the total time of the test for the selection reaction in the feedback mode $(r=0.707)$, the angle at the shoulder joint at the end of the movement $(r=0.995)$, the speed of the fist at the end of the movement $(r=0.982)$, the angle at the elbow joint at the end of the movement $(r=0.978)$, the minimum signal exposure time in the test for the selection reaction in the feedback mode $(r=0.96)$, the speed of the knee $(r=0.918)$ and elbow $(r=$ $0.914)$ movements at the end of the movement, the speed of the elbow at the beginning movement $(\mathrm{r}=$ 0.886 ), time to reach the minimum signal exposure $(\mathrm{r}=0.874)$, angle in the knee joint at the beginning of movement $(\mathrm{r}=-0.845)$, speed of knee movement at the beginning of movement $(r=0.766)$ (Table 4).

It should be noted that the second factor included indicators that reflect the endurance of the nervous system, if necessary, to maintain a high speed and accuracy of response (the number of errors in the selection reaction in the feedback mode with a negative correlation coefficient). The second factor included indicators opposite to the speed of the nervous system under short-term stimuli, reflecting the mobility of the nervous system (total time of the test for the speed of reaction in the feedback mode, the reaction time in the test for the speed of reaction in the feedback mode, the time for reaching the minimum exposure of the signal in the test for the speed of reaction in the feedback mode) with positive correlation coefficients.

Accuracy of movements and accuracy of the nervous system is a manifestation of coordination [13]. Speed and coordination (precision) endurance is oppositely related to the mobility and mobility of the nervous system. This also follows from the general laws of the relationship of various qualities: endurance and speed are antagonists [32]. Also, the 
second factor included indicators of the speed of movements of the shoulder, elbow and fist at the end of the movement with a positive correlation coefficient. This indicates that the second factor reflects the ability to develop speed at the end of the movement, which is typical for people with a large development of endurance. But the second factor also includes the rate of elbow movement at the beginning of the movement, which is a reflection of the speed. In combination with other indicators of the second factor, this is a reflection of speed endurance. That is, the second factor is characterized by a high level of speed and coordination endurance at a relatively lower speed of the nervous system at the beginning of movements and during short-term tasks.
The second factor also included the indicator of the angle in the knee joint with a negative correlation coefficient and the indicator of the knee movement speed with a positive correlation coefficient. That is, to ensure a high level of speed and coordination endurance at a relatively low speed of a simple visual-motor reaction and a choice reaction, leg work acts as a compensatory mechanism. This leads to an increase in the speed of movement, requires greater flexion of the legs in the hip and knee joints and a decrease in the angles in the joints of the legs, in particular, a decrease in the angle in the knee joint [15]. Based on the analysis of the indicators that were included in the second factor, this factor was named "Speed endurance".

Table3

Explained total variance in factor analysis of biomechanical and psychophysiological indicators of qualified veteran boxers

\begin{tabular}{|c|c|c|c|c|c|c|c|c|}
\hline \multicolumn{9}{|c|}{ Total Variance Explained } \\
\hline \multirow{2}{*}{ Component } & \multicolumn{4}{|c|}{ Initial Eigenvalues } & \multicolumn{2}{|c|}{$\begin{array}{c}\text { Extraction Sums of } \\
\text { Squared Loadings }\end{array}$} & \multicolumn{2}{|c|}{$\begin{array}{c}\text { Rotation Sums of Squared } \\
\text { Loadings }\end{array}$} \\
\hline & Total & $\%$ of Variance & \begin{tabular}{|c|} 
Cumulative \\
$\%$
\end{tabular} & Total & $\%$ of Variance & Total & $\%$ of Variance & Cumulative \% \\
\hline 1 & 28.54 & 63.421 & 63.421 & 28.54 & 63.421 & 24.778 & 55.063 & 55.063 \\
\hline 2 & 16.46 & 36.579 & 100 & 16.46 & 36.579 & 20.222 & 44.937 & 100 \\
\hline 3 & 2.77E-15 & $6.15 E-15$ & 100 & & & & & \\
\hline 4 & $2.65 \mathrm{E}-15$ & $5.90 \mathrm{E}-15$ & 100 & & & & & \\
\hline 5 & $2.41 \mathrm{E}-15$ & $5.35 \mathrm{E}-15$ & 100 & & & & & \\
\hline 6 & $2.18 \mathrm{E}-15$ & $4.83 E-15$ & 100 & & & & & \\
\hline 7 & $2.06 \mathrm{E}-15$ & 4.57E-15 & 100 & & & & & \\
\hline 8 & $1.85 \mathrm{E}-15$ & $4.11 \mathrm{E}-15$ & 100 & & & & & \\
\hline 9 & $1.75 \mathrm{E}-15$ & $3.88 \mathrm{E}-15$ & 100 & & & & & \\
\hline 10 & $1.64 \mathrm{E}-15$ & $3.64 \mathrm{E}-15$ & 100 & & & & & \\
\hline 11 & $1.38 \mathrm{E}-15$ & $3.07 E-15$ & 100 & & & & & \\
\hline 12 & $1.34 \mathrm{E}-15$ & $2.98 \mathrm{E}-15$ & 100 & & & & & \\
\hline 13 & $1.27 \mathrm{E}-15$ & $2.82 \mathrm{E}-15$ & 100 & & & & & \\
\hline 14 & $1.02 \mathrm{E}-15$ & $2.26 \mathrm{E}-15$ & 100 & & & & & \\
\hline 15 & 8.17E-16 & $1.82 \mathrm{E}-15$ & 100 & & & & & \\
\hline 16 & $7.51 \mathrm{E}-16$ & $1.67 \mathrm{E}-15$ & 100 & & & & & \\
\hline 17 & $6.84 \mathrm{E}-16$ & $1.52 \mathrm{E}-15$ & 100 & & & & & \\
\hline 18 & $4.99 \mathrm{E}-16$ & $1.11 \mathrm{E}-15$ & 100 & & & & & \\
\hline 19 & $3.82 \mathrm{E}-16$ & $8.48 \mathrm{E}-16$ & 100 & & & & & \\
\hline 20 & $3.46 \mathrm{E}-16$ & $7.68 \mathrm{E}-16$ & 100 & & & & & \\
\hline 21 & $2.01 \mathrm{E}-16$ & $4.46 \mathrm{E}-16$ & 100 & & & & & \\
\hline
\end{tabular}

Notes. Extraction Method: Principal Component Analysis. 


\section{Scree Plot}

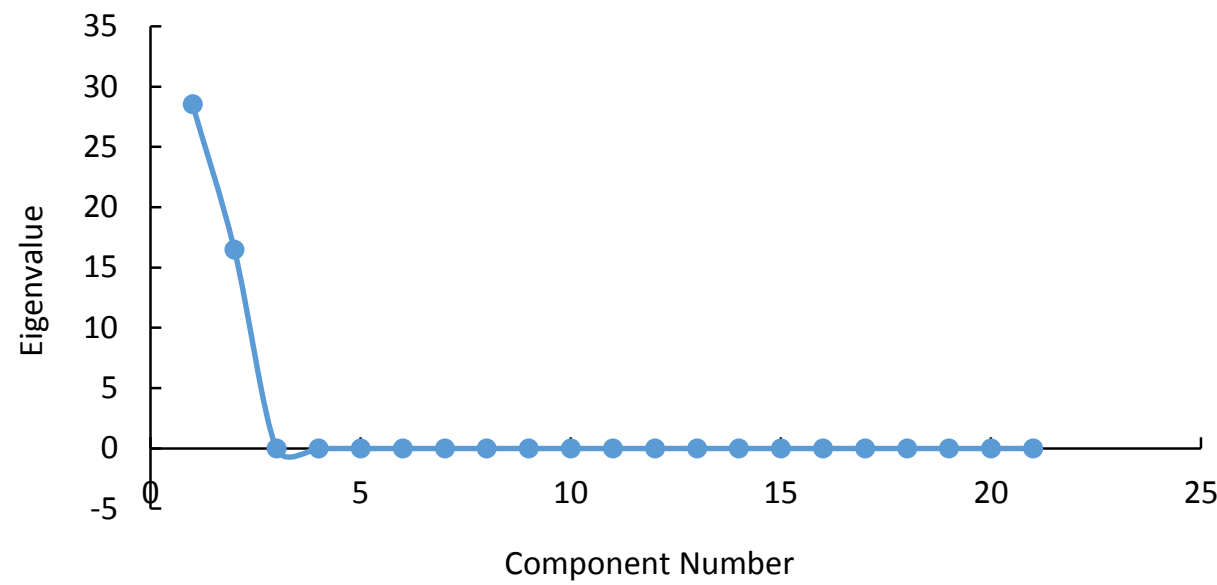

Fig. 2. Component Eigenvalue Plot - Kettell Scree

Table 4

Rotated component matrix in factor analysis of biomechanical and psychophysiological indicators of qualified veteran boxers

\begin{tabular}{|c|c|c|}
\hline \multirow{3}{*}{ Indicators } & \multicolumn{2}{|c|}{ Rotated Component Matrix(a) } \\
\hline & \multicolumn{2}{|c|}{ Component } \\
\hline & $\begin{array}{c}1 \\
\text { «Speed» }\end{array}$ & $\begin{array}{c}2 \\
\text { "Speed and coordination } \\
\text { endurance» }\end{array}$ \\
\hline Shoulder angle at position $3^{*}$ (degrees) & 0.999 & \\
\hline Fist movement speed in position $3\left(\mathrm{~m} \cdot \mathrm{s}^{-1}\right)$ & 0.974 & \\
\hline Shoulder speed in position $3\left(\mathrm{~m} \cdot \mathrm{s}^{-1}\right)$ & 0.972 & \\
\hline Knee angle at position 5 (degrees) & 0.967 & \\
\hline Selection response time (ms) & -0.956 & \\
\hline Simple visual-motor reaction time (ms) & -0.802 & \\
\hline Shoulder speed in position $5\left(\mathrm{~m} \cdot \mathrm{s}^{-1}\right)$ & -0.789 & 0.892 \\
\hline Errors in the test for reaction of choice (number) & 0.782 & -0.985 \\
\hline $\begin{array}{l}\text { Total time to complete the test for the selection reaction in } \\
\text { the feedback mode }(\mathrm{s})\end{array}$ & -0.707 & 0.707 \\
\hline Shoulder angle at position 5 (degrees) & & 0.995 \\
\hline Fist movement speed in position $5\left(\mathrm{~m} \cdot \mathrm{s}^{-1}\right)$ & & 0.982 \\
\hline Elbow angle at position 5 (degrees) & & 0.978 \\
\hline $\begin{array}{l}\text { The minimum exposure time of the signal to the test for the } \\
\text { selection reaction in the feedback mode (ms) }\end{array}$ & & 0.96 \\
\hline Knee speed in position $5(\mathrm{~m} \cdot \mathrm{s}-1)$ & & 0.918 \\
\hline Elbow speed in position $5\left(\mathrm{~m} \cdot \mathrm{s}^{-1}\right)$ & & 0,914 \\
\hline Elbow speed in position $3\left(\mathrm{~m} \cdot \mathrm{s}^{-1}\right)$ & & 0.886 \\
\hline $\begin{array}{l}\text { Time to reach the minimum exposure of the signal in the } \\
\text { test for the selection reaction in the feedback mode }(\mathrm{s})\end{array}$ & & 0.874 \\
\hline Knee angle in position 2 (degrees) & & -0.845 \\
\hline Knee speed in position $2\left(\mathrm{~m} \cdot \mathrm{s}^{-1}\right)$ & & 0.766 \\
\hline
\end{tabular}

Notes. Extraction Method: Principal Component Analysis. Rotation Method: Varimax with Kaiser Normalization. Rotation converged in 3 iterations. Shown are the correlation coefficients of indicators with factors (factor loadings) greater than 0.7. * position 1 - frame 1,0 s from the beginning of the movement (the beginning of the movement); position 2 - frame 2, $0.03 \mathrm{~s}$ from the beginning of the movement; position 3 - frame 3, $0.06 \mathrm{~s}$ from the beginning of the movement; position 4 - frame 4, $0.10 \mathrm{~s}$ from the beginning of the movement; position 5 - frame $5,0.13 \mathrm{~s}$ from the beginning of the movement; position 5 - frame $6,0.16 \mathrm{~s}$ from the beginning of the movement 
Further, the individual factor structure of the athletes' fitness was determined. For this, the percentage values of the severity of each factor were determined for each boxer (Table 5). Table 5 shows that all athletes have different severity of both factors, which indicates the presence of significant individual differences. This should be manifested in different fighting styles and in the need for individual training programs for qualified veteran boxers.

Individual severity of the factors of complex readiness of qualified veteran boxers based on the analysis biomechanical and psychophysiological indicators

\begin{tabular}{|c|c|c|c|c|}
\hline \multirow[t]{2}{*}{ Case } & \multicolumn{2}{|c|}{$\begin{array}{l}\text { Absolute individual values of } \\
\text { factors }\end{array}$} & \multicolumn{2}{|c|}{$\begin{array}{c}\text { Individual values of factors, expressed as a } \\
\text { percentage of the maximum values in the sample } \\
\text { of athletes }\end{array}$} \\
\hline & Factor 1 & Factor 2 & Factor 1 & Factor 2 \\
\hline 1 & 35.50 & 21.50 & 84.52 & 51.19 \\
\hline 2 & 7.50 & 35.50 & 17.86 & 84.52 \\
\hline 3 & 21.50 & 7.50 & 51.19 & 17.86 \\
\hline 4 & 34.68 & 20.72 & 83.19 & 50.26 \\
\hline 5 & 7.68 & 35.79 & 19.65 & 85.64 \\
\hline 6 & 19.86 & 6.48 & 52.28 & 18.75 \\
\hline 7 & 35.50 & 21.50 & 84.52 & 51.19 \\
\hline 8 & 7.50 & 35.50 & 17.86 & 84.52 \\
\hline 9 & 21.50 & 7.50 & 51.19 & 17.86 \\
\hline 10 & 34.68 & 20.72 & 83.19 & 50.26 \\
\hline 11 & 7.68 & 35.79 & 19.65 & 85.64 \\
\hline 12 & 19.86 & 6,48 & 52.28 & 18.75 \\
\hline 13 & 35.50 & 21,50 & 84.52 & 51.19 \\
\hline 14 & 7.21 & 38,64 & 15.59 & 85.58 \\
\hline 15 & 21.50 & 7.50 & 51.19 & 17.86 \\
\hline 16 & 34.68 & 20.72 & 83.19 & 50.26 \\
\hline 17 & 7.21 & 38.64 & 15.59 & 85.58 \\
\hline 18 & 19.86 & 6.48 & 52.28 & 18.75 \\
\hline 19 & 34.68 & 20.72 & 83.19 & 50.26 \\
\hline 20 & 7.50 & 35.50 & 17.86 & 84.52 \\
\hline 21 & 21.50 & 7.50 & 51.19 & 17.86 \\
\hline 22 & 35.50 & 21.50 & 84.52 & 51.19 \\
\hline 23 & 7.21 & 38.64 & 15.59 & 85.58 \\
\hline 24 & 21.67 & 8.50 & 56.19 & 18.86 \\
\hline 25 & 34.68 & 20.72 & 83.19 & 50.26 \\
\hline 26 & 7.50 & 35.50 & 17.86 & 84.52 \\
\hline 27 & 21.50 & 7.50 & 51.19 & 17.86 \\
\hline 28 & 34.68 & 20.72 & 83.19 & 50.26 \\
\hline 29 & 7.68 & 35.79 & 19.65 & 85.64 \\
\hline 30 & 19.86 & 6.48 & 52.28 & 18.75 \\
\hline 31 & 35.50 & 21.50 & 84.52 & 51.19 \\
\hline 32 & 21.67 & 8.50 & 56.19 & 18.86 \\
\hline 33 & 21.67 & 8.50 & 56.19 & 18.86 \\
\hline 34 & 35.50 & 21.50 & 84.52 & 51.19 \\
\hline 35 & 7.21 & 38.64 & 15.59 & 85.58 \\
\hline 36 & 21.50 & 7.50 & 51.19 & 17.86 \\
\hline 37 & 35.50 & 21.50 & 84.52 & 51.19 \\
\hline 38 & 35.50 & 21.50 & 84.52 & 51.19 \\
\hline 39 & 21.50 & 7.50 & 51.19 & 17.86 \\
\hline 40 & 34.68 & 20.72 & 83.19 & 50.26 \\
\hline 41 & 7.21 & 38.64 & 15.59 & 85.58 \\
\hline 42 & 21.67 & 8.50 & 56.19 & 18.86 \\
\hline
\end{tabular}


The analysis of table 5 shows that some athletes (group 1) have a predominant severity of the factor "Speed and coordination endurance" (more than $80 \%$ of the maximum value) and insignificant (less than $30 \%$ of the maximum) severity of the factor "Speed" (athletes 2; 5; 8; 11; 14; 17; 20; 23; 26; 29; 41) $(\mathrm{n}=11))($ Table 5, Fig. 3). This means that these athletes are distinguished by their ability to maintain high speed and accuracy (coordination) of actions for a long time. That is why we named this group "Speed and coordination endurance". This group of athletes, according to their indicators, can be attributed to the style of fighting, requiring a high level of endurance with the support of a relatively high speed of movements. It is logical to assume that these athletes gravitate towards the tempo style of fighting.

In athletes of the second group, the severity of the factor "Speed" prevails (more than $80 \%$ of the maximum) and the average (about 50\% of the maximum) severity of the second factor "Speed and coordination endurance" (athletes No. 1, 4, 7, 10, 13, $16,19,22,25,28,31 ; 32 ; 34 ; 37 ; 38,40(\mathrm{n}=16))$ (Table 5, Fig. 3). That is, these athletes are capable of high-speed actions at the beginning of movements and in average severity of speed and coordination endurance. These qualities are most typical for boxers with a playing style of fighting.

There is also a group of athletes (group 3) in whom the factor "Speed" is less pronounced than in

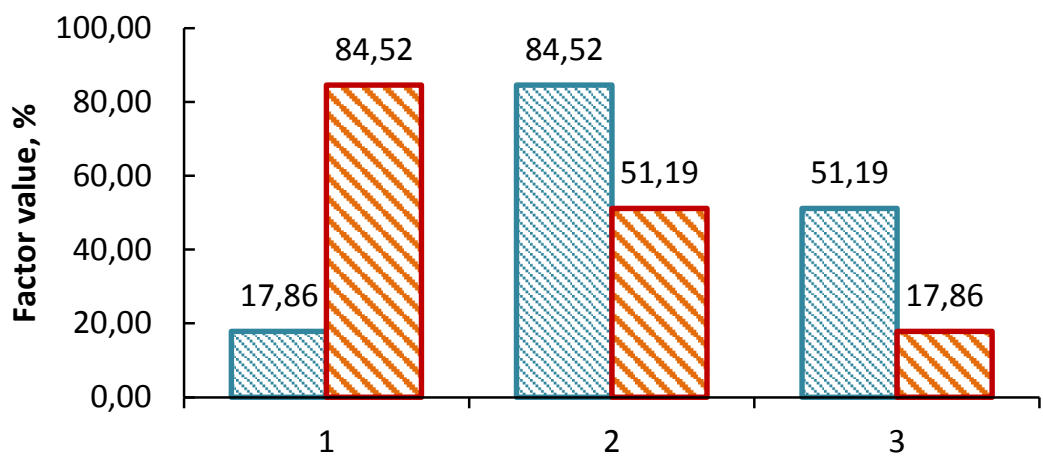

Q Factor 1 BFactor 2

Fig. 3. Individual values of the factors of athletes (examples)

1 - athlete 1, the factor "Speed and coordination endurance" prevails with a slight severity of the factor "Speed" (tempo style of fighting);

2 - athlete 2, the factor "Speed" prevails with an insignificant severity of the factor "Speed and coordination endurance" (playing style of conducting a duel);

3 - athlete 3, the average severity of the "Speed" factor with an insignificant severity of the "Speed and coordination endurance" factor (strength style of fighting)

The analysis of the indicators that were included in each factor, in accordance with the individual severity of the factors, made it possible to determine the individual biomechanical characteristics of athletes - representatives of athletes of the second group and more than in athletes of the first group (about 50\% of the maximum), with a slight severity of the factor "Speed and coordination endurance" ( less than $30 \%$ of the maximum) (athletes No. 3; 6; 9; 12; 15; 18; 21; 24; $27 ; 30 ; 33 ; 35 ; 36 ; 39 ; 42(\mathrm{n}=15))$ (table . 5, Fig. 3). Since all the athletes who participated in the experiment were equally successful in sparring in the ring, it can be considered that the athletes of the third group achieve success due to other qualities, in particular, speed-strength qualities. Speed-strength qualities require the development of maximum and speed [31, 32]. According to Hill's equation, strength and speed are antagonistic qualities and are in a hyperbolic relationship with each other $[31,32]$. Therefore, the maximum value of the product of strength and speed is found with an average expression of both qualities. We did not measure strength in this study because biomechanical analysis does not represent strength capability. We can draw conclusions indirectly about the manifestation of strength abilities. These athletes are characterized by an average manifestation of speed with low endurance. Therefore, we can conclude that these . This the maximum impact force requires the development of power, that is, strength and speed $[3,11]$. 
(the angle between the thigh and the lower leg): the smallest value both at the beginning and at the end of the movement is observed among boxers of the tempo style - "Speed and coordination endurance" (Fig. 4). The same applies to the speed of movement, that is, the speed of movement of the point of the knee joint (Fig. 5). The obtained facts can be explained by the fact that tempo-style boxers compensate for the lower level of speed of nervous processes by the speed of movement, which requires more flexion of the legs in the knee and hip joints.

The speed at the beginning of the movement (0-0.06 s from the beginning of the movement) of the fist and shoulder is the highest among the representatives of the "Speed" group (playing style) (Fig. 5). That is, the speed capabilities determine the execution of movements at maximum speed at the beginning of the movement. Representatives of the groups of tempo style ("Speed and coordination endurance") and power style ("Strength and speed") develop the highest speed at the end of the movement (Fig. 5).

According to the indices included in each factor (Table 4), qualified veteran boxers with a high level of speed and coordination endurance manifestation (tempo style of fighting) are characterized by the least number of errors when performing the test for choice reaction in the feedback mode and average speed development reaction, work in a low stance with a high speed of movement and the development of maximum speed at the end of the movement or evenly throughout the movement.

Qualified veteran boxers with a high level of manifestation of speed capabilities and an average level of manifestation of speed and coordination endurance (playing style of fighting) are characterized by a high level of development of reaction speed, a relatively large number of errors in the test for the choice reaction in the feedback mode, work in a high stance and development of maximum speed at the beginning of the movement.

Qualified veteran boxers with an average level of speed abilities and a low level of speed and coordination endurance manifestation (strength style of fighting) are characterized by a high number of errors when performing the test for the choice reaction in the feedback mode and a high level of development of reaction speed, work in a high stance and development of maximum speed at the end of the movement.

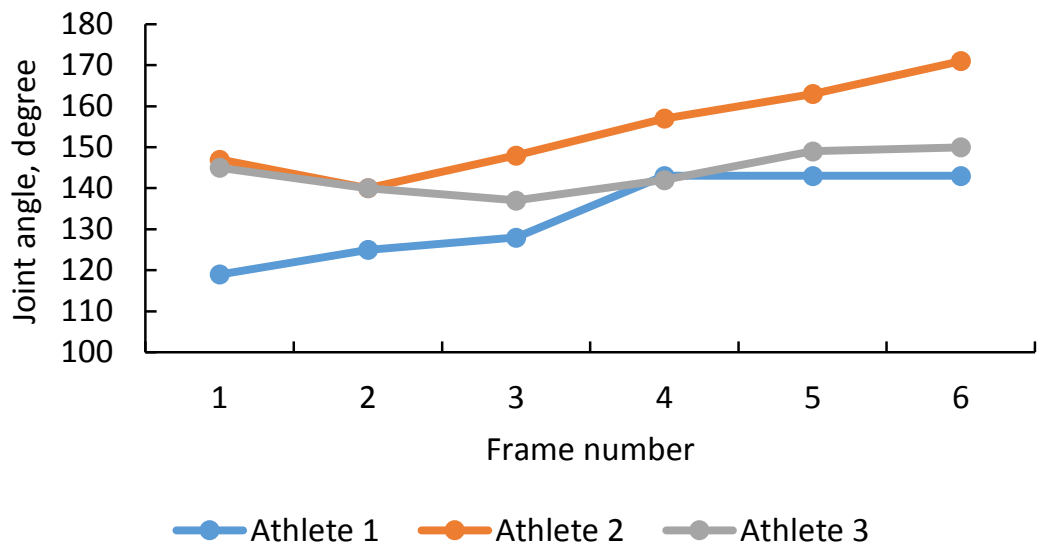

Fig. 4. Examples of the values of the angles between the thigh and the lower leg in qualified veteran boxers of different styles of fighting:

Athlete 1: the factor "Speed and coordination endurance" prevails with a slight severity of the factor "Speed" (tempo style of fighting);

Athlete 2: the factor "Speed" prevails with a slight severity of the factor "Speed and coordination endurance" (playing style of the fight);

Athlete 3: average severity of the "Speed" factor with an insignificant severity of the "Speed and coordination endurance" factor (strength style of fighting);

1 - the initial value of the movement, $0.00 \mathrm{~s}$;

2 - second frame from the beginning of the movement, $0.03 \mathrm{~s}$;

3 - third frame from the beginning of the movement, $0.06 \mathrm{~s}$;

4 - the fourth frame from the beginning of the movement, $0.10 \mathrm{~s}$;

5 - the fifth frame from the beginning of the movement, $0.13 \mathrm{~s}$

6 - the sixth frame from the beginning of the movement, $0.16 \mathrm{~s}$ 

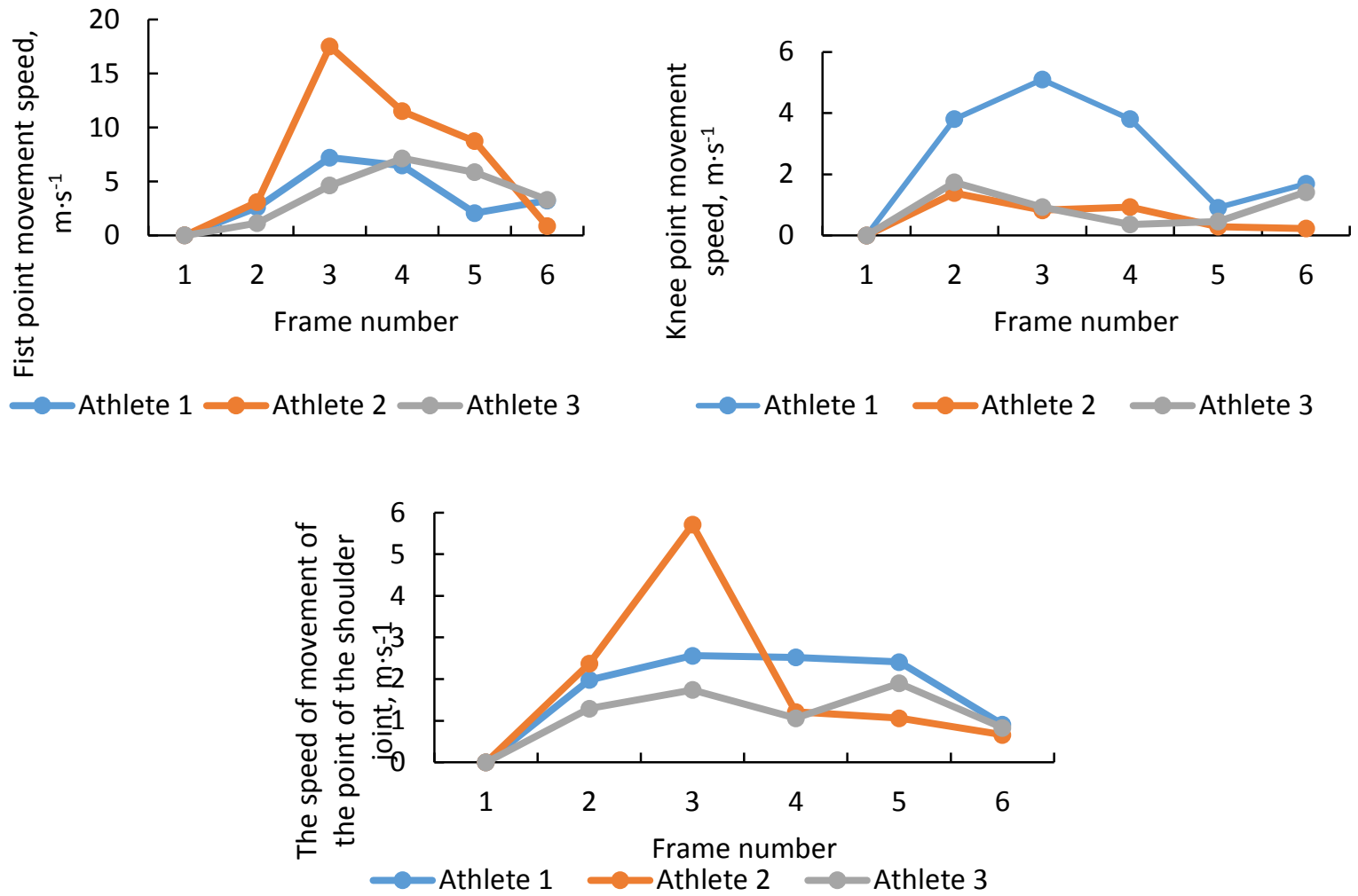

Fig. 5. Examples of the values of the speed of movement of the knee joint, fist and shoulder joint among qualified veteran boxers of different styles of fighting:

Athlete 1: the factor "Speed and coordination endurance" prevails with a slight severity of the factor "Speed" (tempo style of fighting);

Athlete 2: the factor "Speed" prevails with a slight severity of the factor "Speed and coordination endurance" (playing style of the fight);

Athlete 3: average severity of the "Speed" factor with an insignificant severity of the "Speed and coordination endurance" factor (strength style of fighting);

1 - the initial value of the movement, $0.00 \mathrm{~s}$;

2 - second frame from the beginning of the movement, $0.03 \mathrm{~s}$;

3 - third frame from the beginning of the movement, $0.06 \mathrm{~s}$;

4 - the fourth frame from the beginning of the movement, $0.10 \mathrm{~s}$;

5 - the fifth frame from the beginning of the movement, $0.13 \mathrm{~s}$

6 - the sixth frame from the beginning of the movement, $0.16 \mathrm{~s}$

Thus, the psychophysiological features of boxers of different styles of fighting are reflected in the features of the direct strike technique. The lack of speed at the beginning of the movement in tempo style boxers is supplemented and compensated by the high speed of movement. This ensures the maintenance of speed throughout the entire fight and creates the conditions for victory due to the fact that boxers of other fighting styles cannot maintain high endurance for accurate and fast actions for a long time, realizing their potential at the very beginning of the movement. Playing style boxers are characterized by a high speed of movement at the very beginning of the strike. This provides the possibility of short rest breaks and thus creates conditions for variability of actions. Power style boxers are distinguished by the gradual development of the speed of movement, which creates conditions for the implementation of the power of the blow.

\section{Discussion}

As far as we know, this study is one of the first in several respects. This is the first study to determine the style of fighting by combining psychophysiological and biomechanical indicators. It is also one of the first studies to determine the fighting style of veteran boxers. The purpose of our research was to identify the style of fighting veteran boxers based on the individual factor structure of psychophysiological and biomechanical indicators. The set goal assumed that the determination of the individual factor structure of the complex readiness of veteran boxers on the basis of psychophysiological 
and biomechanical indicators will make it possible to determine the hidden relationships between a wide range of psychophysiological and biomechanical indicators, combining the analyzed indicators into groups (factors) and determine the individual severity of each factor in each athlete ...

After analyzing the individual severity of each factor for each athlete, we identified 3 groups of athletes: group 1 - the severity of the factor "Speed and coordination endurance" prevails (more than $80 \%$ of the maximum value) and insignificant (less than $30 \%$ of the maximum) severity of the factor " Speed". This means that these athletes are distinguished by their ability to maintain high speed and accuracy (coordination) of actions for a long time [37-39]. That is why we named this group "Speed and coordination endurance". This group of athletes, according to their indicators, can be attributed to the style of fighting, requiring a high level of endurance with the support of a relatively high speed of movements. It is logical to assume that these athletes gravitate towards the tempo style of fighting.

In athletes of the second group, the severity of the factor "Speed" prevails (more than $80 \%$ of the maximum) and the average (about $50 \%$ of the maximum) severity of the second factor "Speed and coordination endurance" That is, these athletes are capable of high-speed actions at the beginning of movements and in average expressiveness of speed and coordination endurance [40, 41]. These qualities are most typical for boxers with a playing style of fighting.

There is also a group of athletes (group 3) in whom the factor "Speed" is less pronounced than in athletes of the second group and more than in athletes of the first group (about 50\% of the maximum), with a slight severity of the factor "Speed and coordination endurance" ( less than $30 \%$ of the maximum). Since all the athletes who participated in the experiment are equally successful in sparring in the ring, we can assume that the athletes of the third group achieve success at the expense of other qualities, in particular, speed-strength qualities. Speed-strength qualities require the development of maximum power, which is defined as the product of strength and speed. According to Hill's equation, strength and speed are antagonistic qualities and are in a hyperbolic relationship with each other [30-32]. Therefore, the maximum value of the product of strength and speed is found with an average expression of both qualities. We did not measure strength in this study because biomechanical analysis does not represent strength capability. We can draw conclusions indirectly about the manifestation of strength abilities. These athletes are characterized by an average manifestation of speed with low speed endurance. Therefore, we can conclude that these athletes are dominated by strength and speed. This most characterizes the power style of fighting, since the maximum power of the blow requires the development of power, that is, strength and speed.

The goal set in the work was achieved: the styles of conducting a duel of veteran boxers were determined on the basis of the individual factor structure of biomechanical and psychophysiological indicators. We identified 3 groups of athletes, which are characterized by the following manifestations of psychophysiological functions in combination with biomechanical indicators: group 1 - endurance to speed and coordination actions; group 2 - speed at short time intervals; group 3 - power (combination of speed and strength) with a predominance of strength.

It should be noted that the traditional definition of the strength of the nervous system implies 2 manifestations: 1 - resistance to a one-time strong stimulus; 2 - resistance to a long-acting stimulus of medium or low strength $[12,13]$. In our opinion, the concepts of "strength" and "endurance" of the nervous system should be separated by analogy with the classification of physical qualities. This seems to us quite logical, since the muscular apparatus is controlled by the nervous system. Therefore, it is quite natural that the properties of the nervous system, traditionally divided into "strength", "mobility", "poise", should be divided into categories similar to physical qualities: "strength", "endurance", "speed" (quickness) and "switchability" (agility). As for the "speed" of nervous processes, it will be logical that the speed of nerve impulses determines the speed of muscle contractions and, accordingly, the physical quality of speed. The ability to quickly switch from one task to another can also be attributed to the manifestation of the speed of the nervous system. This is typical for the mobility of the nervous system and the physical quality "dexterity" $[12,13]$. These provisions are based on the relationships identified in our study using factor analysis between psychophysiological and biomechanical indicators.

In this regard, it is logical that the strength and speed of the nervous system are antagonists in the same way as physical qualities. Many movements require the development of both strength and speed (jumping, throwing, lifting the barbell). These movements are referred to as movements requiring high power (the product of force and speed). Maximum power is achieved at the level of average development from maximum strength and speed. The same is true for the combinations of endurance and strength, endurance and speed (quickness). The less the strength or speed of the muscle contraction (and, accordingly, the nerve impulse), the longer the muscle contraction can take place. In this case, we 
are talking about endurance, both physical quality and endurance of the nervous system. Therefore, it is quite logical to define the ability to maintain a relatively high speed of movements for a long time as "speed endurance" and to correlate this concept with both physical qualities and the properties of the nervous system. This can explain the fact, obtained in our study, that the maximum speed endurance is observed at relatively low speed indicators.

Thus, the classification of boxers' fighting styles can be represented as a manifestation of physical qualities and properties of the nervous system: "High-speed athletes" (speed prevails), "Endurance athletes" (endurance prevails with average speed development), "Powerful athletes" (average severity prevails) strength and speed). Accordingly, the styles of the duel reflect the manifestations of these physical qualities and properties of the nervous system: tempo style - speed endurance; power style power (strength and speed), play style - speed and switchability (agility).

\section{Prospects for further research}

Further research suggests:

- checking the distribution of qualified veteran boxers by means of cluster analysis;

- identification of differences between boxers of different styles of fighting according to biomechanical and psychophysiological indicators;

- development and substantiation of recommendations regarding the construction of the training process of qualified veteran boxers of different styles of fighting.

\section{Limitations}

The study was conducted on qualified veteran boxers, therefore, the data obtained apply only to the studied contingent. Additional research is needed to disseminate the obtained data to boxers of other age and social groups, as well as to representatives of other sports.

\section{Conclusions}

1 In the structure of the complex readiness of qualified veteran boxers, 2 main factors have been identified. The first factor $(55.063 \%$ of the total variance) according to the indicators included in it, was named "Speed". The second factor $(44.937 \%$ of the total variance) according to the indicators included in it, was named "Speed endurance". The styles of fighting qualified veteran boxers were revealed on the basis of the analysis of the general and individual factor structure of biomechanical and psychophysiological indicators. It is shown that the individual factor structure, which is characterized by the expressiveness of the factor "Speed and coordination endurance" by more than $80 \%$, and the severity of the factor "Speed" by less than $30 \%$, is typical for boxers of the tempo style. The individual factor structure, which is characterized by the expressiveness of the factor "Speed" by more than $80 \%$, and by the severity of the factor "Speed and coordination endurance" by less than $30 \%$, is typical for boxers of the playing style. Individual factorial structure, which is characterized by the expressiveness of the factor "Speed" by more than $50 \%$, and by the severity of the factor "Speed and coordination endurance" by less than $30 \%$, is typical for boxers of the strength style.

2. Qualified veteran boxers with a high level of speed and coordination endurance manifestation (tempo style of fighting), are characterized by the least number of errors when performing the test for the choice reaction in the feedback mode and the average development of the reaction speed, work in a low stance with a high speed of movement and development of maximum speed at the end of the movement or evenly throughout the movement.

Qualified veteran boxers with a high level of manifestation of speed capabilities and an average level of manifestation of speed and coordination endurance (playing style of fighting) are characterized by a high level of development of reaction speed, a relatively large number of errors in the test for the choice reaction in the feedback mode, work in a high stance and development of maximum speed at the beginning of the movement.

Qualified veteran boxers with an average level of speed abilities and a low level of speed and coordination endurance manifestation (strength style of fighting) are characterized by a high number of errors when performing the test for the choice reaction in the feedback mode and a high level of development of reaction speed, work in a high stance and development of maximum speed at the end of the movement.

3. It is shown that the psychophysiological characteristics of boxers of different styles of fighting are reflected in the characteristics of the technique of direct blow. The lack of speed at the beginning of the movement in tempo style boxers is supplemented and compensated by the high speed of movement. Playing style boxers are characterized by a high speed of movement at the very beginning of the strike. Power style boxers are characterized by the gradual development of movement speed. 


\section{Acknowledgments}

The authors are very grateful to all the athletes and coaches who took part in the experiment.

The study was conducted according to: research work on the topic of the Department of Olympic and Professional Sports, Sports Games and Tourism of H.S. Skovoroda Kharkiv National Pedagogical University for 2021-2026: "Development and substantiation of technologies for health promotion and harmonious development of people of different ages and social groups" (№ state registration: 0121U110053).

\section{Conflict of interest}

The authors declare that there is no conflict of interest.

\section{References}

1. Andersen W. Sport and self-love: reflections on boxing and the construction of selfhood. Journal of the Philosophy of Sport. 2021;48(1):129-45.

2. Finlay MJ, Page RM, Greig M, Bridge CA. The prevalence of pre-conditioning and recovery strategies in senior elite and non-elite amateur boxing. Physician and Sportsmedicine. 2021.

3. Korobeynikov G, Aksutin V, Smoliar I. Connection of boxers' combat styles with psycho-physiological characteristics. Pedagogics, psychology, medicalbiological problems of physical training and sports. 2015;19(9):33-7.

https://doi.org/10.15561/18189172.2015.0905

4. Kotarska K, Nowak L, Szark-Eckardt M, Nowak MA. Motivational effect of objectives in practicing karate, boxing, football and wheelchair basketball. Archives of Budo. 2020;16:27-41.

5. Safronov DV, Kozin VYu, Kozina ZhL, Basenko AV, RiabenkovI O, Khrapov SB. Determining the style of conducting a fight of qualified boxers based on neurodynamic indicators using multivariate analysis methods. Health, sport, rehabilitation, 2019; 5(2): 78-87. doi:10.34142/HSR.2019.05.02.09

6. Urzi F, Pokorny B, Buzan E. Pilot Study on Genetic Associations With Age-Related Sarcopenia. Frontiers in Genetics. 2021;11.

7. Narici M, McPhee J, Conte M, Franchi MV, Mitchell K, Tagliaferri $\mathrm{S}$, et al. Age-related alterations in muscle architecture are a signature of sarcopenia: the ultrasound sarcopenia index. Journal of Cachexia Sarcopenia and Muscle. 2021;12(4):973-82.

8. Csete ME. Basic Science of Frailty-Biological Mechanisms of Age-Related Sarcopenia. Anesthesia and Analgesia. 2021;132(2):293-304.

9. Coswig VS, Gentil P, Irigon F, Del Vecchio FB. Caffeine ingestion changes time-motion and technical-tactical aspects in simulated boxing matches: A randomized double-blind PLAcontrolled crossover study. European Journal of Sport Science. 2018;18(7):975-83.

10. Korobejnikov GV, Korobejnikova LG, Kozina ZL. Evaluation and correction of physiological states in sports, Kharkiv, KNPU, 2012.
11. Korobeynikov G, Korobeynikova L, Romanyuk L, Dakal N, Danko G. Relationship of psychophysiological characteristics with different levels of motivation in judo athletes of high qualification. Pedagogics, psychology, medicalbiological problems of physical training and sports. 2017;21(6):272-8.

https://doi.org/10.15561/18189172.2017.0603 doi:10.15561/18189172.2017.0603

12. Lyzohub V, Nechyporenko L, Pustovalov V, Suprunovych V. Specialized training and bioenergy state of football players with different typological properties of the higher parts of the nervous system. Science and Education. 2016;8:107-112; doi: 10.24195/2414-4665-2016-8-21.

13. Korobejnikov GV, Aksjutin VV, Smoljar II. Svjaz stilja vvedenija poedinka bokserov s razlichnymi psihofiziologicheskimi harakteristikami [Relationship of boxing style of introduction of boxers with different psychophysiological characteristics]. Pedagogika, psihologija i medikobiologicheskie problemy fizicheskogo vospitanija $i$ sporta. 2015; 9:33-37.

14. Davis P, Connorton AJ, Driver S, Anderson S, Waldock R. The activity profile of elite male amateur boxing after the 2013 rule changes. Journal of strength and conditioning research. 2018;32(12):3441-6.

15. Bingul BM, Bulgan C, Tore O, Aydin M, Bal E. The effects of impact forces and kinematics of two different stances at straight punch techniques in boxing. Archives of Budo Science of Martial Arts and Extreme Sports. 2017;13:35-9.

16. El-Ashker S, Chaabene H, Negra Y, Prieske O, Granacher U. Cardio-Respiratory Endurance Responses Following a Simulated 3 × 3 Minutes Amateur Boxing Contest in Elite Level Boxers. Sports. 2018;6(4).

17. Howell DR, Meehan WP, Loosemore MP, Cummiskey J, von Rosenberg JPG, McDonagh D. Neurological tests improve after Olympic-style boxing bouts: a pretournament and post-tournament study in the 2016 Women's World Boxing Championships. British Journal of Sports Medicine. 
2017;51(17):1279-84

18. Finlay MJ, Greig M, Page RM. Quantifying the physical response to a contemporary amateur boxing simulation. Journal of Strength and Conditioning Research. 2018;32(4):1005-12.

19. Shadmehr R, Wise S. The computational neurobiology of reaching and pointing: a foundation for motor learning. Cambridge, Mass.: MIT Press. 2005. ISBN 978-0-262-19508-9. OCLC 54529569.

20. Paul M, Ganesan S, Sandhu JS, Simon JV. Effect of sensory motor rhythm neurofeedback on psychophysiological, electro-encephalographic measures and performance of archery players. Ibnosina $J$. Med. Biomed. Sci. 2011:32-39.

21. Deary IJ, Der G, Ford G. Reaction times and intelligence differences; a population-based cohort study. Intelligence. 2001;29(5):389-399. doi:10.1016/S0160-2896(01)00062-9.

22. Hedayatpour N, Falla D. Physiological and Neural Adaptations to Eccentric Exercise: Mechanisms and Considerations for Training. BioMed Research International. 2015;(15):7. https://doi.org/10.1155/2015/193741.

23. Cacioppo J, Tassinary LG, Berntson GG. The handbook of psychophysiology, $3^{\text {rd }}$ ed. New York: Cambridge University Press; 2007.

24. Bart K, Steinberg H. The Contributions of the EastGerman Sports Medicine Specialist and Neurologist Bernhard Schwarz (1918-1991) in the Field of Boxing. Sportverletzung-Sportschaden. 2018;32(1):66-74.

25. Boroushak N, Khoshnoodi H, Rostami M. Investigation of the Head's Dynamic Response to Boxing Punch Using Computer Simulation. Montenegrin Journal of Sports Science and Medicine. 2021;10(1):31-5.

26. Chen MA, Spanton K, van Schaik P, Spears I, Eaves D. The Effects of Biofeedback on Performance and Technique of the Boxing Jab. Perceptual and Motor Skills. 2021;128(4):1607-22.

27. Lenetsky S, Brughelli M, Nates RJ, Neville JG, Cross MR, Lormier AV. Defining the Phases of Boxing Punches: A Mixed-Method Approach. Journal of Strength and Conditioning Research. 2020;34(4):1040-51.

28. Kozina ZL, Goloborodko YA, Boichuk YD, Sobko IM, Repko OO, Bazilyuk TA, et.al. The influence of a special technique for developing coordination abilities on the level of technical preparedness and development of psycho-physiological functions of young volleyball players 14-16 years of age. Journal of Physical Education and Sport. 2018; 18(3):14451454. DOI:10.7752/jpes.2018.03214

29. Kozina ZL, Cieslicka M, Prusik K, Muszkieta R, Sobko IN, Ryepko OA, Bazilyuk TA, Polishchuk SB, Osiptsov AV, Korol SA.Algorithm of athletes' fitness structure individual features' determination with the help of multidimensional analysis (on example of basketball). Physical education of students.

2017;21(5):225-238

http://dx.doi.org/10.15561/20755279.2017.0505

30. Kozina Z. Factor models of the physical preparedness of volleyball players of a high class of various game role. Pedagogy, Psychology and medical and biological problems of physical education and sport, 2007;9: 80-85.

31. Kozina ZhL. Algoritm sistemnogo analiza v nauchnykh issledovaniyakh $\mathrm{v}$ oblasti sportivnykh igr [Algorithm for systems analysis in scientific research in the field of sports games]. Fizicheskoye vospitaniye studentov tvorcheskikh spetsial'nostey. 2006; 1(4): 15-26

32. Kozina ZhL. Analiz i obobshchenie rezul'tatov prakticheskoj realizacii koncepcii individual'nogo podkhoda $\mathrm{v}$ trenirovochnom processe $\mathrm{v}$ sportivnykh igrakh [Analysis and generalization of results of practical realization of individual approach conception in trainings of sport games]. Fizicheskoe vospitanie studentov tvorcheskikh special'nostej. 2009; 2: 34-47.

33. Kozin S, Safronov D, Kozina Z, Kniaz H, Proskurnia O, Prontenko K, Lahno O, Goncharenko V, Kholodniy A. Comparative biomechanical characteristics of one-arm hang in climbing for beginners and qualified athletes. Acta of Bioengineering and Biomechanics. 2020;22(1):5767.DOI: 10.37190/ABB-01440-2019-03.

34. Kozin S, Kozina Z, Korobeinik V, Cieślicka M, Muszkieta R, Ryepko O, Boychuk Yu, Evtifieva I, Bejtka M. Neuro-muscular training for injury prevention of students-rock climbers studying in the specialty "Physical Education and Sports": a randomized study. Journal of Physical Education and Sport. 2021;21(Suppl. issue 2):1251 - 1259.

35. Kozina Z,.Barybina L, Mishchenko D, Tsikunov A, Kozin A.The program "Psychodiagnostics" as a means of determining psycho-physiological characteristics and functional state in the physical education of students. Physical education of students. 2011;3:56-59.

36. Kozina ZhL, Slyusarev VF, Volkov EP. Efektivnist' zastosuvannia netradicijnoi formi autogennogo trenuvannia dlia vidnovlennia pracezdatnosti basketbolistiv [Effectiveness of non-traditional form of autogenic training for recreation of basketball players; workability]. Pedagogics, psychology, medical-biological problems of physical training and sport. 2001; 14: 8-15

37. Le Blanc C. Huai nan tzu; Philosophical Synthesis in Early Han Thought: The Idea of Resonance (Kanying) With a Translation and Analysis of Chapter Six. Hong Kong: Hong Kong University Press, 1985.

38. Pujszo M, Jasińska N, Wyżlic P, Duda J, Stępniak R. Comparative analysis of psychic resilience of men and women training combat sports. Quality in Sport. 2019;5(2):58-65

39. Follmer B, Varga AA, Zehr EP. Understanding concussion knowledge and behavior among mixed martial arts, boxing, kickboxing, and Muay Thai 
athletes and coaches. Physician and Sportsmedicine. 2020;48(4):417-23.

40. Cañizares Hernández M, Soler Prieto Y, Domínguez García J, Suárez Rodríguez M. Factors affecting concentration of attention in boxing athletes in combat situations Los factores que afectan la concentración de la atención en atletas de boxeo en situaciones de combate. Podium Revista de Ciencia y Tecnología en la Cultura Física. 2020;15(1):5-21.

41. Di Virgilio TG, Ietswaart M, Wilson L, Donaldson DI, Hunter AM. Understanding the Consequences of Repetitive Subconcussive Head Impacts in Sport: Brain Changes and Dampened Motor Control Are Seen After Boxing Practice. Frontiers in Human Neuroscience. 2019;13.

\section{Information about authors}

Kozin V.Yu.

zhanneta.kozina@gmail.com

http://orcid.org/0000-0003-2561-8803

Kinesiology laboratory

H.S. Skovoroda Kharkiv National Pedagogical University

Altshevskih str. 29, Kharkiv, 61002, Ukraine

\section{Boychuk Yu.D.}

rector@hnpu.edu.ua

https://orcid.org/0000-0002-4891-769X

doctor of pedagogical sciences, professor, Corresponding Member of the NAPS of Ukraine, rector H.S. Skovoroda Kharkiv National Pedagogical University

Altshevskih str. 29, Kharkiv, 61002, Ukraine

\section{Skaliy A.V.}

skaliy@wp.pl

orcid.org/0000-0001-7480-451X

Institute of Sport and Physical Culture University of Economy in Bydgoszcz, Poland

Garbary str., 26, 85-229 Bydgoszcz, Poland

\section{Zelenskiy R.M.}

zelenskiyroman69@ukr.net

https://orcid.org/0000-0002-3351-5460

Associate Professor at the Department of Gymnastics, Musical and Rhythmic Education and Fitness, H.S. Skovoroda Kharkiv National Pedagogical University

Altshevskih str. 29, Kharkiv, 61002, Ukraine

\section{Honcharenko V.I.}

honcharenko_v@ukr.net

https://orcid.org/0000-0002-7606-2182

Classical professional college of the Sumy state university, Sumy, Ukraine

Rimsky-Korsakov Street, 2, Sumy, Sumy region, 40,000, Ukraine

\section{Cieślicka M.}

cudaki@op.pl

http://orcid.org/0000-0002-04072592

Nicolaus Copernicus University in Toruń, Ludwik Rydygier Collegium Medicum in Bydgoszcz

Bydgoszcz, Kujawsko-pomorskie, Poland

\section{Bejtka M.}

cudaki@op.pl

https://orcid.org/0000-0002-2240-4896

Nicolaus Copernicus University in Torun, Ludwik Rydygier Collegium Medicum in Bydgoszcz

Bydgoszcz, Kujawsko-pomorskie, Poland 
Козін В.Ю.

\section{Інформація про авторів}

zhanneta.kozina@gmail.com

http://orcid.org/0000-0003-2561-8803

Лабораторія кінезіології

Харківський національний педагогічний університет імені Г.С. Сковороди

вул. Алчевських 29, Харків, 61002, Україна

Altshevskihstr. 29, Kharkiv, 61002, Ukraine

\section{Бойчук Ю.Д.}

rector@hnpu.edu.ua

https://orcid.org/0000-0002-4891-769X

доктор педагогічних наук, професор, член-кореспондент АПН України, ректор

Харківський національний педагогічний університет імені Г.С. Сковороди

вул. Алчевських 29, Харків, 61002, Україна

\section{Скалій О.В.}

skaliy@wp.pl

https://orcid.org/0000-0001-7480-451X

Інститут Спорту і Фізичної Культури Університет Економіки в м. Бидгощ, Польща

вул. Грабарі, 29, Бигдощ, Польща

\section{Зеленський P.M.}

zelenskiyroman69@ukr.net

https://orcid.org/0000-0002-3351-5460

Доцент кафедри гімнастики, музично-ритмічного виховання і фітнесу

Харківський національний педагогічний університет імені Г.С. Сковороди

вул. Алчевських 29, Харків, 61002, Україна

\section{Гончаренко B.I.}

honcharenko_v@ukr.net

https://orcid.org/0000-0002-7606-2182

Класичнийй фаховий коледж Сумськиого державниого університету

вулиця Римського-Корсакова, 2, Суми, Сумська область, 40000, Україна

\section{Цесліцка М.}

cudaki@op.pl

http://orcid.org/0000-0002-0407-2592

Університет Миколи Коперника в Торуні

Бидгощ, Куявсько-Поморське воєводство, Польща

\section{Бейтка М.}

radek@muszkieta.co

https://orcid.org/0000-0002-2240-4896

Університет Миколи Коперника в Торуні

Бидгощ, Куявсько-Поморське воєводство, Польща

\section{Козин В.Ю.}

\section{Информация об авторах}

zhanneta.kozina@gmail.com

http://orcid.org/0000-0003-2561-8803

Лаборатория кинезиологии

Харьковский национальный педагогический университет имени Г.С. Сковороды ул. Алчевских 29, Харьков, 61002, Украина

Бойчук Ю.Д.

rector@hnpu.edu.ua

https://orcid.org/0000-0002-4891-769X

доктор педагогических наук, профессор, член-корреспондент АПН Украины, ректор Харьковский национальный педагогический университет имени Г.С. Сковороды ул. Алчевских 29, Харьков, 61002, Украина 
Скалий А.В.

skaliy@wp.pl

http://orcid.org/0000-0001-7480-451X

Институт Спорта и Физической Культуры

Университет Экономики в г. Быдгощ, Польша

Ул Грабари, 2, 85-229, Быгдош, Польша

\section{Зеленский Р.Н.}

zelenskiyroman69@ukr.net

https://orcid.org/0000-0002-3351-5460

Доцент кафедры гимнастики, музыкально-ритмического воспитания и фитнеса

Харьковский национальный педагогический университет имени Г.С. Сковороды

ул. Алчевских 29, Харьков, 61002, Украина

\section{Гончаренко В.И.}

honcharenko_v@ukr.net

https://orcid.org/0000-0002-7606-2182

Классический профессиональный колледж Сумского государственного университета

улица Римского-Корсакова, 2, Сумы, Сумская область, 40000, Украина

\section{Цеслицка М.}

cudaki@op.pl

http://orcid.org/0000-0002-0407-2592

Университет Николая Коперника в Торуне

Быдгощ, Куявско-Поморское воеводство, Польша

\section{Бейтка М.}

radek@muszkieta.co

https://orcid.org/0000-0002-2240-4896

Университет Николая Коперника в Торуне

Быдгощ, Куявско-Поморское воеводство, Польша

This work is licensed under a Creative Commons Attribution 4.0 International License (CC BY 4.0)

Received: 2021-08-17 Accepted: 2021-09-09 Published: 2021-09-25 